University of Louisville

ThinkIR: The University of Louisville's Institutional Repository

Electronic Theses and Dissertations

6-2015

\title{
Fibroblast-derived extracellular matrix: an alternative cell culture substrate that alters lung cancer cell line phenotype.
}

Michael Thomas Scherzer

University of Louisville

Follow this and additional works at: https://ir.library.louisville.edu/etd

Part of the Biomedical Engineering and Bioengineering Commons

\section{Recommended Citation}

Scherzer, Michael Thomas, "Fibroblast-derived extracellular matrix: an alternative cell culture substrate that alters lung cancer cell line phenotype." (2015). Electronic Theses and Dissertations. Paper 1995.

https://doi.org/10.18297/etd/1995

This Master's Thesis is brought to you for free and open access by ThinkIR: The University of Louisville's Institutional Repository. It has been accepted for inclusion in Electronic Theses and Dissertations by an authorized administrator of ThinkIR: The University of Louisville's Institutional Repository. This title appears here courtesy of the author, who has retained all other copyrights. For more information, please contact thinkir@louisville.edu. 
FIBROBLAST-DERIVED EXTRACELLULAR MATRIX: AN ALTERNATIVE CELL CULTURE SUBSTRATE THAT ALTERS LUNG CANCER CELL LINE PHENOTYPE

\author{
By
}

Michael Thomas Scherzer

B.S., University of Louisville

\author{
A Thesis \\ Submitted to the Faculty of the \\ University of Louisville \\ J.B Speed School of Engineering \\ As Partial Fulfillment of the Requirements \\ For the Professional Degree
}

\title{
MASTER OF ENGINEERING
}

Department of Bioengineering

June 2015 
FIBROBLAST-DERIVED EXTRACELLULAR MATRIX: AN ALTERNATIVE CEL CULTURE SUBSTRATE THAT ALTERS LUNG CANCER CELL LINE PHENOTYPE

\author{
Submitted by: \\ Michael T. Scherzer \\ A Thesis Approved On \\ (Date)
}

By the Following Reading and Examination Committee

Dr. Levi Beverly, Thesis Director

Dr. Patricia Soucy

Dr. Gail Depuy 


\section{ACKNOWLEDGEMENTS}

The author would like to fully expression his appreciation to everyone involved in his academic and scientific career as a whole. Thank you to Dr. Levi Beverly for this opportunity and your mentorship that will help me throughout life. Thank you to Dr. Patricia Soucy for her mentorship and materials. Thank you to everyone in the Levi Beverly, Leah Siskind, and Patricia Soucy Labs for their help and encouragement. Thank you to the Brown Cancer Center, Department of Bioengineering, J.B Speed School of Engineering, and to the University of Louisville. Finally, thank you to my friends and family for the support over the past 6 years. 


\begin{abstract}
Poor lung cancer survival can largely be contributed to the metastatic cells that invade and spread throughout the body. The tumor microenvironment (TME) is composed of multiple cell types, as well as non-cellular components. The TME plays a critical role in the development of metastatic cancers by providing migratory cues that change the growing tumor's properties. The Extracellular Matrix (ECM), a main component of the TME, has been shown to change composition during tumor progression, allowing cancer cells to invade tissue and survive away from the primary cancer site. Although the ECM is well-known to influence the fate of tumor progression, little is known about the molecular mechanisms that are affected by the cancer cellECM interactions. It is imperative that these mechanisms are understood in order to properly understand and prevent lung cancer dissemination. However, common in vitro studies do not incorporate these interactions into everyday cell culture assays. In our lab, we have adopted a model that examines decellularized human fibroblast-derived ECM as a 3D substrate for growth of lung adenocarcinoma cell lines. It is hypothesized that the interactions between lung cancer cell lines and fibroblast-derived ECM will alter phenotypes important for lung cancer progression. Here, we have characterized the effect of various fibroblast-derived matrices on the properties of various lung cancer adenocarcinoma cell lines. Such altered processes include morphology, growth, and migration. This work highlights the significance of the cell-ECM interaction and its requirement for incorporation into in vitro experiments. Implementation of a fibroblast-derived ECM as an in vitro technique will provide researchers with an important factor to manipulate to better recreate and study the TME.
\end{abstract}




\section{TABLE OF CONTENTS}

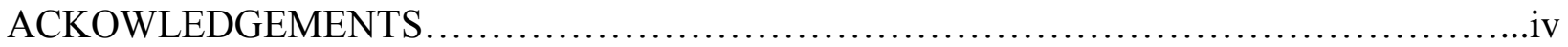

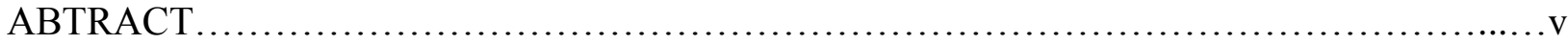

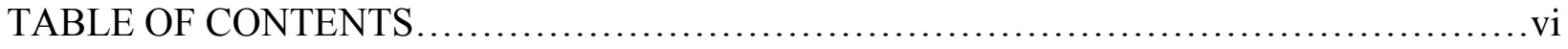

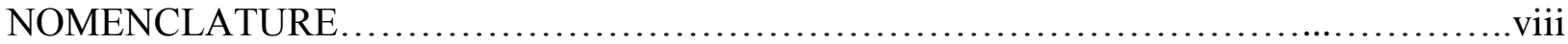

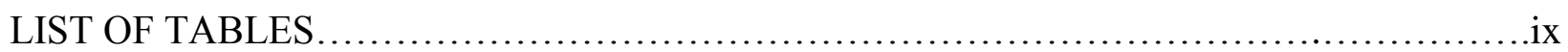

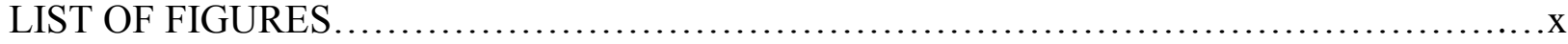

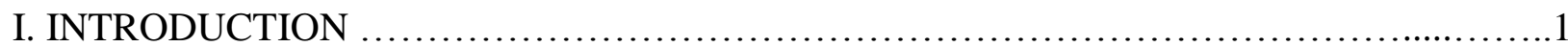

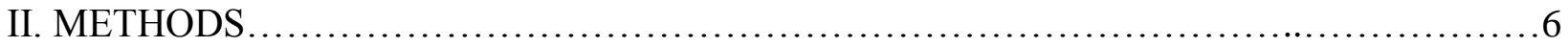

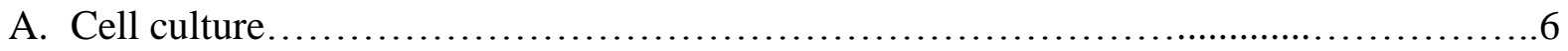

B. ECM Production and Decellularization.................................................

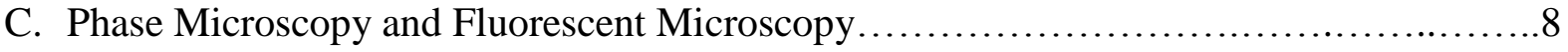

D. SDS PAGE and Western Blot.....................................................

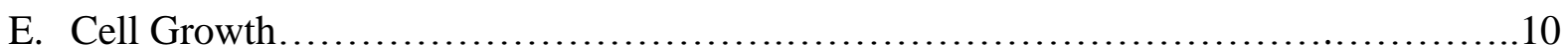

F. Trans-well Migration Assay....................................................... 11

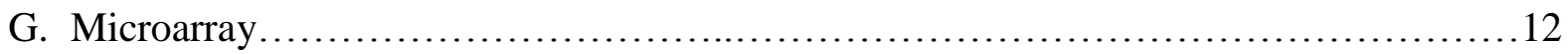

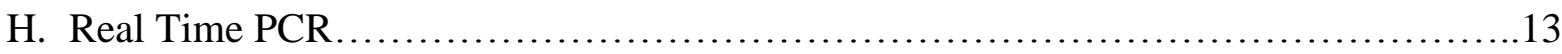

I. Time-Lapse Microscopy............................................................

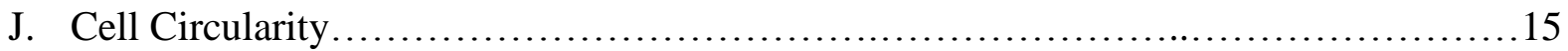

K. Subcutaneous Tumor Formation....................................................

L. Dose Response of Chemotherapeutics........................................... 16

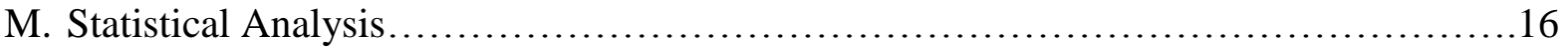




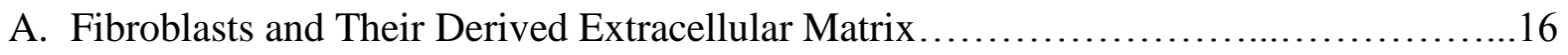

B. Fibroblast-derived Matrices Alter Lung Cancer Cell Morphology......................18

C. Fibroblast-derived Matrices Alter Lung cancer Cell Growth.........................20

D. Fibroblast-Derived Matrices alter functional protein levels of lung cancer cell lines.....22

E. Fibroblast Derived Matrices Do not alter Drug Resistance of Lung Cancer Cell Lines...25

F. Fibroblast Derived Matrices Protect Lung Cancer Cells from Serum Deprivation........27

G. Fibroblast-Derived Matrices Change mRNA levels of Various Genes in Lung Cancer

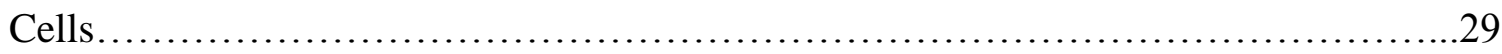

H. Fibroblast-Derived Matrices can Induce Lung Cancer Cells to Migrate..................36

I. Fibroblast-derived ECM increase Subcutaneous Xenograft Tumor Formation in Mice...38

IV. CONCLUSIONS AND FUTURE WORK .......................................40



VI. REFERENCES ..............................................................63 


\section{NOMENCLATURE}

$\mu \mathrm{m}=$ micrometer

ASNS=Asparagine Synthase

$\mathrm{BCA}=$ Bicinchoninic acid

BCAT1 = Branched-chain amino acid transaminase 1

$\mathrm{BME}=$ basement membrane extract

CAFs $=$ Cancer-associated fibroblasts

$\mathrm{CREB}=$ Cyclic-AMP responsive Element Binding

$\mathrm{ECM}=$ Extracellular Matrix

EMT $=$ Epithelial-to-Mesenchymal transition

FAK = Focal Adhesion Kinase

FAP $=$ fibroblast-activated protein

$\mathrm{FBS}=$ fetal bovine serum

GAGs $=$ Glycosaminoglycans

IL-8 = Interleukin - 8

KCNMA1 = Potassium Large Conductance Calcium-Activated Channel family M

LOX = Lysyl Oxidase

MAPK = Mitogen-activated Protein Kinase

MMPs = Matrix metalloproteases

MOMP = mitochondrial outer membrane permeablization

MRNA $=$ messenger ribonucleic acid

MTOR = mammalian target of Rapamycin

$\mathrm{NH}_{4} \mathrm{OH}=$ Ammonium Hydroxide

NSCLC $=$ Non-small cell lung cancer

$\mathrm{NT5E}=5$ ' nucleotidase

PSAT1 = phosphor-serine aminotransferase 1

$\mathrm{QPCR}=$ quantitative polymerase chain reaction

TBS-T $=$ Tris-buffered saline with Tween-20

TIMP $=$ tissue inhibitors of metalloproteases

$\mathrm{TME}=$ Tumor Microenvironment

VEGF $=$ Vascular Endothelial Growth Factor 


\section{LIST OF TABLES}

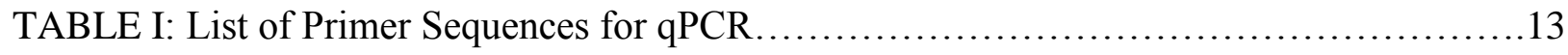

TABLE II: Common Ranked Down-regulated Genes between Both A549 and H358 on WI38

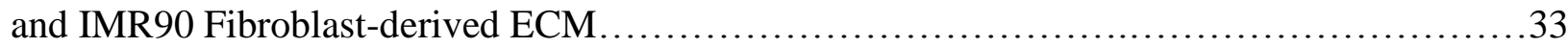

TABLE III: Common Ranked Up-regulated Genes between Both A549 and H358 on WI38 and

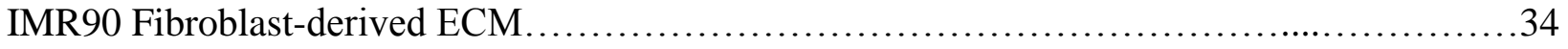

TABLE IV: A549 Serum Deprivation Statistical Analysis................................42

TABLE V: H358 Serum Deprivation Statistical Analysis................................43

TABLE VI: HPL1D Serum Deprivation Statistical Analysis.............................45

TABLE VII: ECM Protein Statistical Analysis.........................................46

TABLE VIII: Time-lapse Statistical Analysis......................................47

TABLE IX: Directionality Statistical Analysis.......................................48

TABLE X: Circularity Statistical Analysis ........................................... 49

TABLE XI: A549 Cell Counting Statistical Analysis......................................49

TABLE XII: H358 Cell Counting Statistical Analysis........................................51

TABLE XIII: HPL1D Cell Counting Statistical Analysis..................................52

TABLE XIV: A549 Alamar Blue Statistical Analysis.....................................54

TABLE XV: H358 Alamar Blue Statistical Analysis.....................................55

TABLE XVI: HPL1D Alamar Blue Statistical Analysis...................................5 57

TABLE XVII: Xenograft Volume Statistical Analysis....................................58

TABLE XVIII: Xenograft Weight Statistical Analysis.......................................59

TABLE XIX: Trans-well Migration Statistical Analysis.................................60 


\section{LIST OF FIGURES}

FIGURE 1: The Tumor Microenvironment............................................

FIGURE 2: Schematic of Fibroblast-derived ECM protocol ...............................8

FIGURE 3: Depiction of Trans-well Assay.............................................. 12

FIGURE 4: Fibroblasts and their ECM............................................... 18

FIGURE 5: Fibroblast-derived ECM alter Lung Cancer Cell Line Morphology...............20

FIGURE 6: Fibroblast-derived ECM alter Lung Cancer Cell Growth.......................22

FIGURE 7: Fibroblast-derived ECM alters Protein Levels of A549 Cells.......................24

FIGURE 8: Fibroblast-derived ECM do does not alter drug response to Gemcitabine and

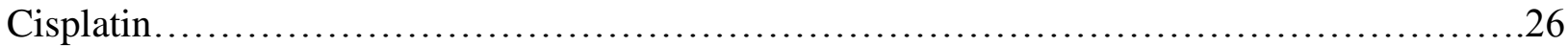

FIGURE 9: Fibroblast-derived ECM Protects Lung Cancer Cell Lines from Serum

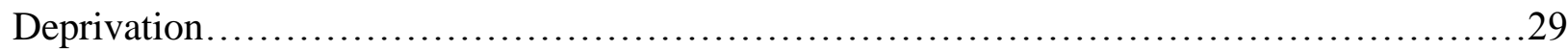

FIGURE 10: Fibroblast-derived ECM alters mRNA profile of A549 and H358 Cells...........32

FIGURE 11: Fold Change of mRNA by Quantitative qPCR ................................35

FIGURE 12: Fibroblast-derived ECM alter Cell Migration of Lung Cancer Cell Lines in a Trans-

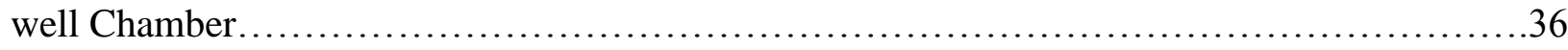

FIGURE 13: Fibroblast-derived ECM induce Directional Migration..........................38

FIGURE 14: Fibroblast-derived ECM Increase Subcutaneous Tumor Formation of A549 Cells in

Mice . .40 




\section{Introduction}

The five-year survival rate for stage 3 lung cancer patients is only around 15\% (American Cancer Society, 2015). This poor survival rate is largely contributed to the metastatic form of the disease, which allows the cancer to become a systemic burden, by infiltrating vital organs. 40\%$50 \%$ of patients with Non-small-cell lung cancers (NSCLC), which is the classification for nearly $80 \%$ of all lung cancers, have metastatic lung cancer at diagnosis (Ihde et al., 1992). Although survival rates improve with early detection, there is a great need for efficacious therapies that treat the metastatic form of lung cancer. There are many FDA approved therapies that are successful for lung cancer patients (eg. surgical resection, local radiation, and chemotherapeutics), but few therapies exist that are effective at specifically targeting cancer cells, while leaving healthy cells untouched, and even fewer that are effective against the metastatic cancers. This failure to produce effective therapies is partly due to false discoveries that are attributed to lack of appropriate models that accurately recapitulate the in vivo mechanisms that drive lung cancer and its progression to metastasis (Hoelder et al., 2012). For instance, many cancer therapies are developed from chemicals that illicit a cancer specific cytotoxic response during in vitro cell culture environments, but these cell culture environments do not offer the full biological repertoire that is present in the human disease. This means that researchers are limited in the accuracy of their conclusions thus leading them down an incorrect path that may ultimately result in failure in the clinical setting. Although cell culture experiments 
are a simple first-line test for new therapies, an improved in vitro model could filter out inefficacious treatments before large financial and temporal investments are made.

It is now a fully accepted paradigm that neoplasms are a dynamic environment that host multiple cell types that influences the behavior and outcome of the cancer (Wood et al., 2014). Many studies are being done to determine the exact role the tumor microenvironment (TME) constituents, which include cancer cells, immune cells, fibroblasts, vasculature, and the extracellular matrix (ECM) (Schwendener et al., 2014) (Figure 1). The immune cells have been heavily studied for their role in carcinogenesis because they can support tumor growth and influence angiogenesis by secreting the necessary growth factors, which include VEGF and IL-8 (Wood et al., 2014). Cancer-associated fibroblasts (CAFs), which are fibroblasts that reside within the tumor, but differ from normal resident fibroblasts, have also been shown to be protumorigenic by providing growth factors TGF- $\beta$, PDGF, and FGF, as well as cytokines such as IL-8, CXCL14, and IL-6 (Cirri et al., 2011). Many novel therapies have been produced that target the TME. For instance, Bevacizumab is a monoclonal antibody that inhibits lung cancer angiogenesis by targeting VEGF (Das et al., 2012). It is clear that the best way to treat the patient is to treat the entire TME. 


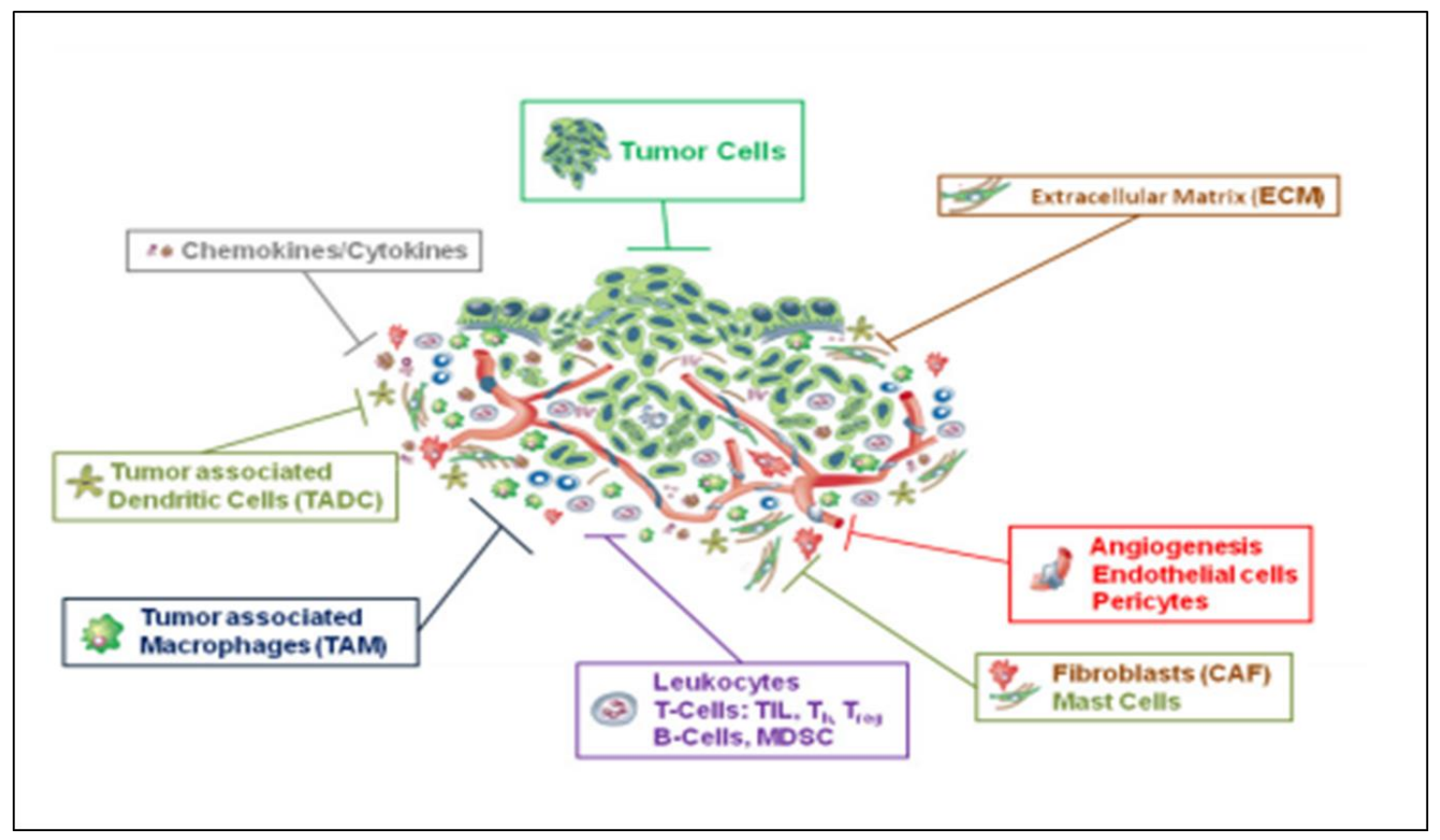

Figure 1- The Tumor Microenvironment

The ECM, an essential constituent of the TME, is a meshwork of protein fibers and glycosanimoglycans (GAGs) that not only provides mechanical support, but also offers growth and migration cues through growth factors, adhesion interactions, and mechano-transduction (Oskarsson et al., 2013). The ECM is generally secreted and organized by fibroblasts, but other cells can contribute to ECM production, such as endothelial and epithelial cells (Lu et al., 2012). Lately, the ECM has been heavily researched for its role in the progression of lung and breast carcinomas (Lu et al., 2012; Oskarsson et al., 2013; Yang et al., 2011). The balance of ECM deposition and ECM degradation can potentiate diseases such as fibrosis and cancer (Cox et al., 2011). Increased production of the high elastic modulus collagen and decreased low elastic modulus elastin expression can stiffen local tissue, therefore altering mechano-transduction pathways (Butcher et al., 2009). Matrix metalloproteases (MMPs) are matrix-degrading enzymes 
that can degrade the ECM and alter its elasticity, which can provide cells with important biomechanical stimulation to direct invasion into surrounding tissue and blood vessels, leading to metastasis (Hadler-Olsen et al., 2013). Alternately, ECM can be stiffened by increased matrix production and deposition of collagen via Lysyl Oxidase (LOX) signaling (Gao et al., 2010). For instance, ECM accumulation by increased Collagen deposition has been documented in many tumor cell types, including glioma, breast, and lung cancers (Huijbers et al., et al; Caccavari et al., 2010). This abnormal ECM function can cause changes in the mechano-transduction pathways that regulate growth and migration pathways. Tension-induced signaling has been shown to affect Mitogen-Activated Protein Kinase (MAPK) signaling pathways by p44/42 activation in fetal lung epithelial cell lines (Copland et al., 2007). MAPK signaling is highly affected in cancer that activates many downstream applications. Similarly, focal adhesions are the point of cell-ECM matrix interaction and are comprised of integrins that cluster together and bind the ECM, thus triggering downstream pathways mediated through Focal Adhesion Kinase (FAK) (Caccavari et al., 2010). These downstream signaling pathways have the ability to modulate MMP and tissue inhibitors of metalloproteases (TIMP) that can adjust ECM synthesis and degradation (Caccavari et al., 2010). It is now evident that there exists a complex feedback mechanism between cancer cells and ECM that influences the fate of the tumor (Blaauboer et al., 2014). Interference of the cancer-promoting ECM-cell interactions could immobilize cancer cells and inhibit the deadly metastatic form of lung cancer, thus improving patient survival rates. Therefore, more basic research is needed to understand how lung ECM affects lung cancer cells, and vice versa. 
To improve the reconstruction of the in vivo TME in vitro, cancer researchers are growing cancer cells in three-dimensions, rather than the commonly used 2D- tissue culturedtreated dishes. Matrigel ${ }^{\mathrm{TM}}$, a basement membrane extract $(\mathrm{BME})$ harvested from EHS mouse sarcoma cells, is a common semi-solid medium used to recapitulate the in vivo environment that affects cell morphology, proliferation, migration, and drug response ( Benton et al., 2011). There also exists synthetic cell scaffolds such as hyaluronic acid, gelatin, or polyethylene, but these synthetic gels and substrates lack the rich diversity of the stroma-associated ECM that is present in vivo. Also, both Matrigel ${ }^{\mathrm{TM}}$ and synthetic matrices lack the native fibrillar architecture that may be required for the complex mechanisms of the cancer cell-ECM interaction. Also, BME, like Matrigel ${ }^{\mathrm{TM}}$, are not tissue specific, which could make interpreting effects difficult because different ECM protein compositions could have different effects on the biology of the tissuespecific cancer cell. Although suspending cancer cells in 3D protein gels better mimic the native tumor, it does not accurately recapitulate many tumors of the epithelium, including lung adenocarcinoma. Therefore, it is necessary to implement a better tissue-culture technique that incorporates signals from extracellular matrix proteins and structural properties.

Fibroblast-derived ECM could be a simple, cost-effective cell culture technique that recapitulates the ECM-lung cancer cell interactions that have been shown to play a vital role in the progression of cancer. Fibroblasts are the principal contributors to ECM synthesis in most types of tissue, including the lung epithelium. Therefore, an ECM synthesized by fibroblast that retains its structural architecture will more accurately represent the native tumor environment. Edna Cukierman et al have published numerous articles describing techniques to harvest mouse fibroblast-derived matrices, and even characterized how these matrices affect the morphology, 
growth, and drug response of numerous epithelial tumors cell lines, but no lung adenocarcinoma cells with human lung matrix were tested (Serebriiskii et al., 2008). Further, the same group demonstrated that overexpression of Fibroblast-activated Protein (FAP) in 3T3 cells induced matrix fiber alignment, which increased the growth invasiveness of pancreatic cancer cells (Lee et al., 2011). Still, little is known about how human lung fibroblast-derived matrices alter the morphology, growth, invasiveness, and biochemical properties of lung cancer cell lines.

In this work, we sought to better understand the effect of tissue-specific, human lung fibroblast-derived matrices on two lung adenocarcinoma cell lines, A549, H358, and HPL1Ds in ways previously untested with fibroblast-derived ECM. Techniques such as cell growth assays, drug response, microscopy, western blot, RNA analysis, and migration studies were used to characterize human fibroblast-derived ECM and how they affect lung cancer cell lines. The Objective of this Masters of Engineering project is to characterize the effect of human fibroblastderived extracellular matrix on lung cancer cell phenotypes. Also, it is a long-term goal of the student to understand how modulation of the fibroblast-derived extracellular matrix alters human lung cancers.

\section{METHODS}

\section{A. Cell Culture}

Three Human fibroblast cell lines were used in this study, IMR-90, WI-38, and HDF, were all purchased from ATCC. IMR-90 Cells are human lung fibroblasts harvested from a female of 16-week gestation. WI-38 cells are also lung fibroblasts harvested from a 12-week old fetus. HDFs are human dermal fibroblast procured from the Patricia Soucy Laboratory. IMR90 and 
HDF cells were both cultured in RPMI 1640 (Hyclone SH30027.01) supplemented with 10\% FBS (Hyclone SH30070.03), 1\% penicillin-streptomycin (Hyclone SV30030), and 1\% Lglutamine (Hyclone SH30034.01). WI-38 cells were cultured in MEM media (Gibco 10370-021) supplemented with 10\% FBS, $1 \%$ penicillin-streptomycin, and 1\% L-Glutamine.

Three-epithelial cell lines, A549, H358, and HPL1D, purchased from ATCC, were used to seed onto Fibroblast-derived matrix. A549 and H358 cells are both lung adenocarcinoma cells harvested in 1972, and 1981, respectively. HPL1D cells are normal peripheral lung epithelial cells and were used to compare the cancerous phenotype of A549 and H358 cell lines to normal, steady-state lung epithelial cells. However, HPL1D cells have been shown to form soft-agar colonies in our lab, suggesting they are transformed. All epithelial cells were cultured in RPMI 1640 supplemented with $10 \%$ FBS, $1 \%$ Glutamine, and $1 \%$ penicillin-streptomycin.

\section{B. Extracellular Matrix Production and Decellularization}

ECM production and harvesting protocols were adapted from Cukierman et al and Soucy et al (Soucy et al., 2009). Fibroblasts are seeded at confluence, and cultured for 8 days while changing the media every two days. HDF cells are a little larger that the lung fibroblast cell lines so they are seeded at a lower density than WI-38 and IMR-90 cells. For example, in a 6 well dish, 300,000 IMR90 or WI-38 cells are seeded, but for the same size dish, 270,000 HDF cells were seeded. After 8 days of culture, cells are washed once with PBS (Hyclone SH30028.02), and then incubated at room temperature for 2 minutes in PBS with $50 \mathrm{mM}$ concentration of ammonium Hydroxide ( $\left.\mathrm{NH}_{4} \mathrm{OH}\right)$ (Fischer-A669-500) with .05\% Triton X-100 (Sigma T8787) solution. Ammonium hydroxide is used to destroy the fibroblasts by creating a hypotonic 
solution that lyses the cells. Triton X-100 is a detergent that also aides in cell lysis while leaving the produced matrix undisturbed. Cells are constantly observed under the microscope at 10X to confirm proper removal of all fibroblast debris. After decellularization, the matrices are washed 3 times with PBS. To prevent unwanted fibroblast DNA, which could affect downstream applications, matrices are incubated at for one hour at $37^{\circ} \mathrm{C}$ in a $20 \mathrm{U} / \mathrm{mL}$ DNAse 1 (Thermo Scientific EN0525) concentration in sterile H2O (CellGro 25-055-CV). After DNAse 1 treatment, matrices are washed 3 times with PBS and either stored at $4{ }^{\circ} \mathrm{C}$, or used immediately (Figure 2).

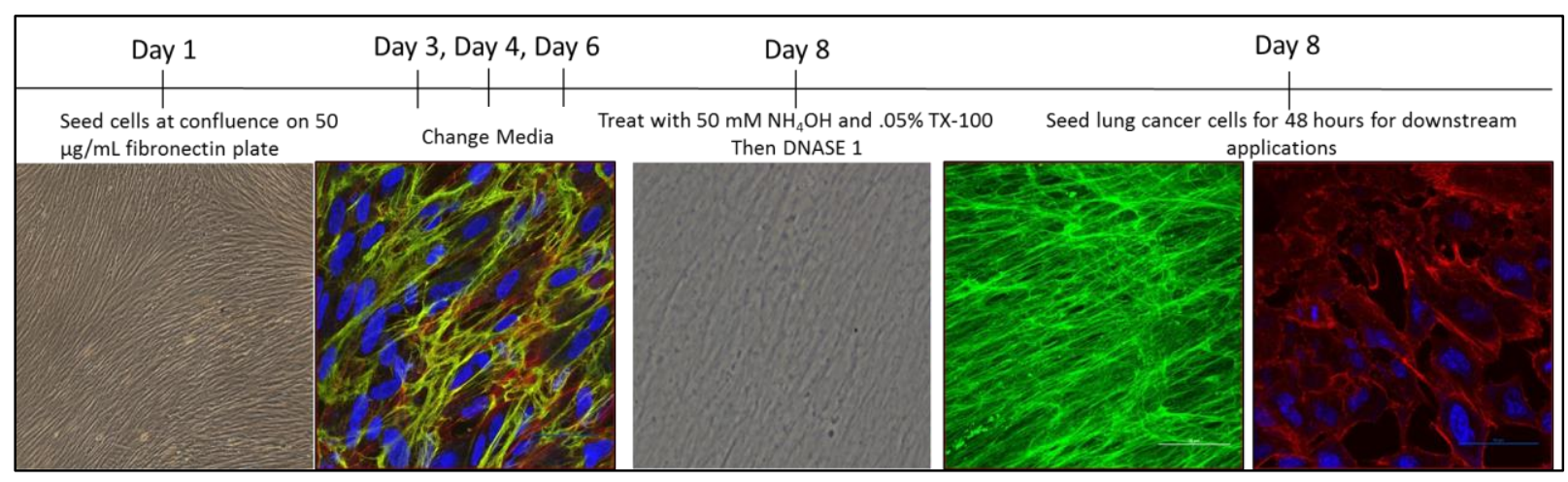

Figure 2- Schematic of Fibroblast-derived ECM protocol

\section{Microscopy and Fluorescent Microscopy}

For light microscopy, a Zeiss AX10 inverted microscope was used at 10X and 40X. For Immunofluorescence, a Nikon A1R camera mounted on a Zeiss Confocal microscope was used. For immunofluorescence, Matrices and/or cells were fixed with 4\% formaldehyde in PBS for 20 minutes at room temperature then washed 3 times with PBS for 5 minutes each. For ECM staining, a succinimidyl ester (NHS ester) conjugated to an Alexa Fluor 488 dye was incubated at a concentration of $10 \mu \mathrm{g} / \mathrm{mL}$ for 30 minutes at $37^{\circ} \mathrm{C}$, then washed 3 times with PBS for 5 
minutes. The NHS ester binds to any proteins, thus staining the entire extracellular matrix. To ensure no leftover fibroblast DNA is present, DAPI was also added at a concentration of 1:1000 in PBS for 10 minutes at room temperature. To image the cytoskeleton of epithelial cells, Phalloidin was added at a concentration of 1:1000, while incubating with DAPI for 10 minutes at room temperature. After staining, the cells were imaged. The ECM stain fluoresces at $488 \mathrm{~nm}$, while Phalloidin and DAPI fluoresce at $600 \mathrm{~nm}$ and $358 \mathrm{~nm}$, respectfully.

\section{SDS PAGE and Western Blot}

Cells were lysed in CHAPS buffer (1\% CHAPS in $150 \mathrm{nM}$ NACL, $50 \mathrm{mM}$ TRIS pH 7.5, 50 mM EDTA) containing protease and phosphatase inhibitors for 20 minutes on ice. Lysates were centrifuged at $15,000 \mathrm{X} \mathrm{G}$ for 8 minutes at $4^{\circ} \mathrm{C}$ to pellet the insoluble material, which includes the extracellular matrix proteins. Protein concentration was then quantified using a bicinchoninic acid (BCA) assay (Thermo Scientific \#23228, \#1859078). Briefly, the BCA assay is a 2-step reaction where peptide bonds reduce the copper sulfate in reagent- $\mathrm{A}$, next the reduced copper is chelated by the bicinchonic acid from reagent-B, forming a purple color, which can be measured at $562 \mathrm{~nm}$ by absorption on a spectrophotometer. The amount of reduced copper ions and therefore the absorbance at $562 \mathrm{~nm}$ is directly proportional to the amount of protein in the sample. $30 \mu \mathrm{g}$ of total protein was loaded on a 4-12\% bis-tris polyacrylamide gel (Novex). 150 volts was applied across the gel for 60 minutes at room temperature while the gel was submerged in 1X running buffer (Novex NP0002) in water. After protein migration, gels were either stained with colloidal blue (Invitrogen LC6025) for 4 hours to stain nonspecific proteins, or 
immunoblotting was performed. For immunoblotting, protein was transferred to a PVDF membrane by applying a voltage of $70 \mathrm{~V}$ for 60 minutes in $1 \mathrm{X}$ transfer buffer (Novex NP0006) diluted with water and methanol. After protein transfer, membranes were washed for 15 minutes in 5\% milk in a mixture of Tris-buffered saline and Tween 20 (TBS-T) to block non-specific binding by the antibody. Primary antibodies specific to human GAPDH, AKT, phosphorylated AKT, p38, phosphorylated p38, p44/42, phosphorylated p44/42, E-cadherin, Vimentin, mTOR, phosphorylated mTOR, and CDC42 (Cell Signaling ${ }^{\mathrm{TM}}$ ) were added at a concentration of 1:10000 in $5 \%$ milk and incubated with the membranes overnight at $4^{\circ} \mathrm{C}$. After primary antibody incubation, membranes were washed 3 times in $5 \%$ milk for 5 minutes. Secondary antibody, conjugated to HRP, specific to target the primary rabbit antibody, was incubated with the membranes in $1.25 \%$ milk for 30 minutes at room temperature then washed 2 times for 5 minutes in $1.25 \%$ milk. Membranes were then incubated for 20 minutes in TBS-T before adding HRP substrate (Thermo Scientific \#34095) for detection by luminescence captured on a photographic film. The amount of luminescence produced by the HRP enzymatic reaction is proportional to the amount of protein tagged by the antibody.

\section{E. Cell Growth}

To determine the effect of cell-derived matrices on cell growth and proliferation, two assays were employed. To determine cell number, 30,000 cells were plated in a 12 well dish with a fibronectin coat, or fibroblast-derived ECM. Every 24 hours for 4 days, cells were washed in PBS, trypsinized in Trypsin (Hyclone SH30042.01) for 3 minutes at $37^{\circ} \mathrm{C}$, centrifuged at 1200 RPM for 3 minutes and suspended in $1 \mathrm{~mL}$ media for counting with Trypan Blue ${ }^{\mathrm{TM}}$ (Invitrogen 
T10282) in a Countess automated cell counter m (Invitrogen). Trypan blue is a dye used to stain dead cells, which does not stain live cells.

For proliferation, 2,000 cells were seeded into a 96 well-plate, and Alamar Blue ${ }^{\mathrm{TM}}$ (Invitrogen 612130) was added each day for 4 days to determine proliferation. Plates were incubated at $37^{\circ} \mathrm{C}$ until a color changed was observed, then read on a spectrophotometer using an excitation of $560 \mathrm{~nm}$ and emission of $590 \mathrm{~nm}$. Briefly, Alamar Blue ${ }^{\mathrm{TM}}$ is resazurin and enters the cell and gets reduced by cells with an active metabolism. The reaction converts a blue resazurin to a purple resorufin, a fluorescent molecule. Raw fluorescent data were averaged, with the blank reading subtracted, and then normalized to Fibronectin.

\section{F. Trans-well Migration Assay}

To determine if fibroblast-derived matrices affected how epithelial cells migrate, trans-well chamber (Fischer 353097) assays were used. Briefly, ECM was produced on the bottom side of a trans-well chamber (Figure 3A-C) and A549 cells were cultured on the top side (Figure 3D). After 24 and 48 hours, non-migrating cells were scraped off the membrane. Migrating cells were then fixed in 4\% paraformaldehyde and stain with hemotoxylin and eosin (Protocol 122-911). Membranes were then mounted on a glass slide and migrated cells were counted using ImageJ software analysis. $\mathrm{N}=4$. 


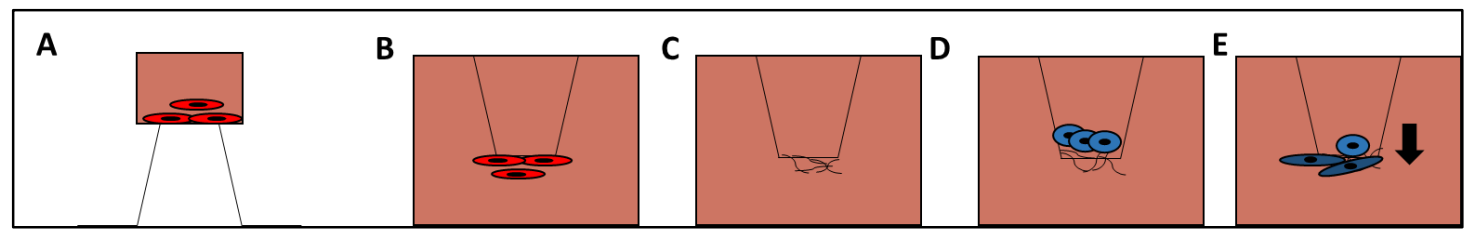

Figure 3- Depiction of Trans-well Assay. (3A) Seed 50,000 fibroblasts on membrane and allow to adhere. (3B) Properly insert chamber 28 hours seeding. (3C) After 8 days, decellularize. (3D) seed 15,000 A549 Cells in upper portion of chamber. (3E) allow cells to migrate for 24 hours.

\section{G. Microarray}

RNA was harvested using E.Z.N.A Total RNA Kit (Omega) and analyzed on a nanodrop for quality control. RNA must have a 260/280 absorbance ratio between 1.8 and 1.9, and a 260/230 absorbance ratio between 1.9 and 2.2 to ensure minimal protein contamination then treated with DNAse to remove DNA contamination. RNA samples were then converted to cDNA, labeled, and hybridized on an Affymetrix PrimeView Human Array Chip with the aid of the Genomics Core Facility and the assistance of the student. Raw intensity scores were imported into Partek Genomics Suite $6.6(6.13 .0731)$ and normalized on a gene level using the standard RMA algorithm for normalization and background correction. A 2-way ANOVA was set up and a stepup FDR corrected P-value was included for every P-value calculated. Only significant gene changes with a P-value of $<.05$ and a fold change greater than 1.5 were uploaded into MetaCore $^{\mathrm{TM}}$ for pathway and gene otology analysis. 


\section{H. Real Time PCR}

New biological replicates were used to generate RNA as previously described for the microarray. Complementary DNA was generated using the RNA to cDNA kit Applied Biosystems). This kit uses thymidine-rich primers that bind to the poly-A tail of mRNA and allow a polymerase to synthesize the complete complimentary strand. Oligonucleotide sequences are as follows:

Table I

List of Primer sequences for Quantitative PCR

\begin{tabular}{|l|l|l|}
\hline Gene & Sense & Antisense \\
\hline LGALS & GGTCAACCCTGAAGATCACAG & GTCCAATGAGTTGCAGACAATG \\
\hline PSAT1 & AAGGTGTGCTGACTATGTGG & TTGAGGTTCCAGGTGCTTG \\
\hline ASNS & AGGAGAGTGAGAGGCTTCTG & GGTGGCAGAGACAAGTAATAGG \\
\hline BCAT1 & AATCCCAAGTATGTAAGAGCCTG & AAGAGATGAGCCGTAATTCCC \\
\hline IL-8 & ATACTCCAAACCTTTCCACCC & TCTGCACCCAGTTTTCCTTG \\
\hline STAT4 & CCTGAAAACCCTCTGAAGTACC & ACCTTTGTCACCCCTTTCTG \\
\hline C3 & AACTACATCACAGAGCTGCG & AAGTCCTCAACGTTCCACAG \\
\hline C1S & TTTGTAGATGTCCCTTGTAGCC & AATCTCCCCAATCAGTGCAG \\
\hline MMP7 & TTCCAAAGTGGTCACCTACAG & AGTTCCCCATACAACTTTCCTG \\
\hline RND1 & ATGTAAGCTCGTTCTGGTCG & CTCTGTTCCTCTGTCTCCAAAC \\
\hline GAPDH & TGCACCACCAACTGCTTAGC & GGCATGGACTGTGGTCATGAG \\
\hline
\end{tabular}


Primers were designed to be between 18-22 base pairs long, have a 40\%-60\% GC content, and amplify a product between $60-120$ base-pairs. Primer specificity was validated to only amplify one product between at $60^{\circ} \mathrm{C}$. Reaction efficiency was also validated to ensure that fluorescence intensity doubled each cycle using a serial dilution of a known cDNA template. Reactions were shown to be efficient between $10 \mathrm{ng}$ and $50 \mathrm{ng}$ concentrations of DNA. To qualify, efficiency must be within $85 \%$ and $105 \%$ with an $\mathrm{R}^{2}$ value greater than .98 . This quality control confirms that no matter the differences in original starting material between the wells, comparison of threshold values are valid because the samples are within the linear range. To calculate relative fold change compared to a fibronectin-coated dish, the $2{ }^{\Delta \Delta C}$ T method. Equations shown below:

$$
\begin{gathered}
\Delta \triangle C T=(\triangle C T(E C M)-\triangle C T(F N)) \\
\Delta C T=\text { Average } C T(\text { Target gene })-\text { Average } C T(G A P D H) .
\end{gathered}
$$

$\mathrm{C}_{\mathrm{T}}$ is the PCR cycle number where the fluorescent threshold value is reached. All PCR reactions were analyzed on a biorad CX96.

\section{TIME-LAPSE MICROSCOPY}

150,000 A549 cells were seeded onto either ECM-coated or Fibronectin-coated 35mm dishes with a coverslip insert for microscopy. 24 hours after cell seeding, dishes were inserted into a live-cell chamber for 24 hours and pictures were taken at 3 different fields every 10 minutes, until 24 hours have past. Cell migration was calculated by tracking $4-8$ cells per field throughout the time lapse. Cell tracking was achieved by the MtrackerJ plugin, available for ImageJ 
(Meijering et al., 2012). Average point by point velocity for all lines were calculated within MtrackerJ and reported with SEM. Directionality, a measure to determine linearity of migration, was calculated by D/d (Figure 13B).

\section{J. Cell Circularity}

After confocal microscopy with Phallodin and DAPI, images with scale bars were imported in ImageJ and converted from RGB to 32-bit and a threshold was set to create maximum contrast between cell borders and empty space. Built-in functions of ImageJ allowed for easy image segmentation for area and perimeter analysis. Circularity is a value between $0-1$ with 1 being a perfect circle (Pasqualato et al., 2013).

$$
\text { Circularity }=4 \pi \times\left(\text { Area } \div \text { Perimeter }^{2}\right)
$$

\section{K. Subcutaneous Tumor Formation}

$5 \times 10^{6}$ cells in $500 \mu \mathrm{L}$ were mixed with either $500 \mu \mathrm{L}$ PBS or $500 \mu \mathrm{L}$ of PBS with $615 \mu \mathrm{g}$ scraped WI38 derived ECM. $100 \mu \mathrm{L}$ was then injected in the subcutaneous tissue of NRG mice. Each mouse received two injections: $100 \mu \mathrm{L}$ of A549 cells with ECM on the left flank and 100 $\mu \mathrm{L}$ of A549 with PBS on the right flank. Tumors were then allowed to form and after 60 days, mice were euthanized by $\mathrm{CO} 2$ and tumors were excised and fixed in $10 \%$ buffered formaldehyde. Fixed tissues were sent to HistoServe ${ }^{\mathrm{TM}}$ for paraffin embedding, sectioning, and staining. Tumor volume is measured by: 


$$
\text { Tumor Volume }=\frac{1}{2}(\text { Lenth } x \text { Width })^{2}
$$

Where length is the greatest longitudinal direction and width is the greatest transverse direction (Jensen et al., 2008).

\section{Dose Response of Chemotheraputics}

3,000 A549, H358, and HPL1D cells were seeded in on a 96 well-plate. After 24 hours, Cisplatin and Gemcitabine were added into the media and then incubated for 48 hours before measuring cell growth by Alamar Blue ${ }^{\mathrm{TM}}$. $\mathrm{N}=3$.

\section{Statistical Analysis}

A two-way ANOVA with a Tukey's Test for multiple comparisons were used to determine statistical significance. For in vivo data, a unpaired t-test was performed. *, Pvalue $<.05$

III. Results and Discussion

\section{A. Fibroblasts and Their Derived Extracellular Matrix}

In order to derive accurate conclusions, multiple fibroblast cell lines were procured to produce a variety of ECM from multiple tissue types. Two human fetal lung fibroblasts cell lines, WI38 and IMR-90, and one human dermal fibroblast cell line, HDF, were used. All fibroblast cell lines exhibited the same spindle-shaped morphological features (Figure 4Ai). 
Interestingly, all three fibroblast cell lines aligned themselves in a linear pattern, and produced a similar ECM, which also appeared highly linearized, suggesting there is dynamic remodeling after cell seeding (Figure 4Aii and 4Aiii). This linearized ECM could be important for maximizing physiologic relevance to the human disease in vitro, which is not available with solubilized ECM, such as Matrigel ${ }^{\mathrm{TM}}$. The resultant fibroblast-derived ECM was solubilized in 5M Guanidine-HCL and protein content was measured using a BCA assay (figure 4C). All fibroblast-derived matrix produced similar amounts of ECM per $\mathrm{cm}^{2}$, except HDF produces slightly more (P=045). WI38 ECM averaged $32.06 \mu \mathrm{g} / \mathrm{cm}^{2}+/-3.961$, IMR-90 ECM averaged 32.02+/-3.299 $\mu \mathrm{g} / \mathrm{cm}^{2}$, and HDF ECM averaged 34.016 +/- $3.990 \mu \mathrm{g} / \mathrm{cm}^{2}$. Results were averaged from three wells of fibroblast-derived matrix solubilized in the same volume. Interestingly, HDF produce an ECM that has significantly $(\mathrm{p}=.045)$ more protein than the other fibroblast-derived ECM (Figure 4B), thus providing suggesting that there are differences in ECM production between tissue-specific fibroblasts. After solubilizing, ECM protein was analyzed by SDS-PAGE and total protein was stained by colloidal blue (Figure 4D). Interestingly, both WI38 and IMR90 derived matrices have more intense Collagen bands (140 kDa- $175 \mathrm{kDa}$ ) compared to HDF. However, HDF-derived ECM has a greater presence of a fibronectin band (260 kDa-280 kDa) compared to WI38 and IMR90 matrices. Collagen and Fibronectin bands are easily identified because they have been previously shown to be the prominent constituent of WI38 derived ECM (Soucy et al., 2009). Also, there appears to be more intermediate protein bands that range between $175 \mathrm{kDa}$ and $250 \mathrm{kDa}$ that are more prominent in HDF derived ECM than WI38 and IMR90 ECM. However, it is not possible to conclusively determine the identity these proteins. It is interesting that there are differences in ECM protein expression between cell lines from two 
distinct tissue sources. These subtle differences in protein expression might alter the phenotype of lung cancer cell lines, thus potentially affecting the outcome of the human disease.

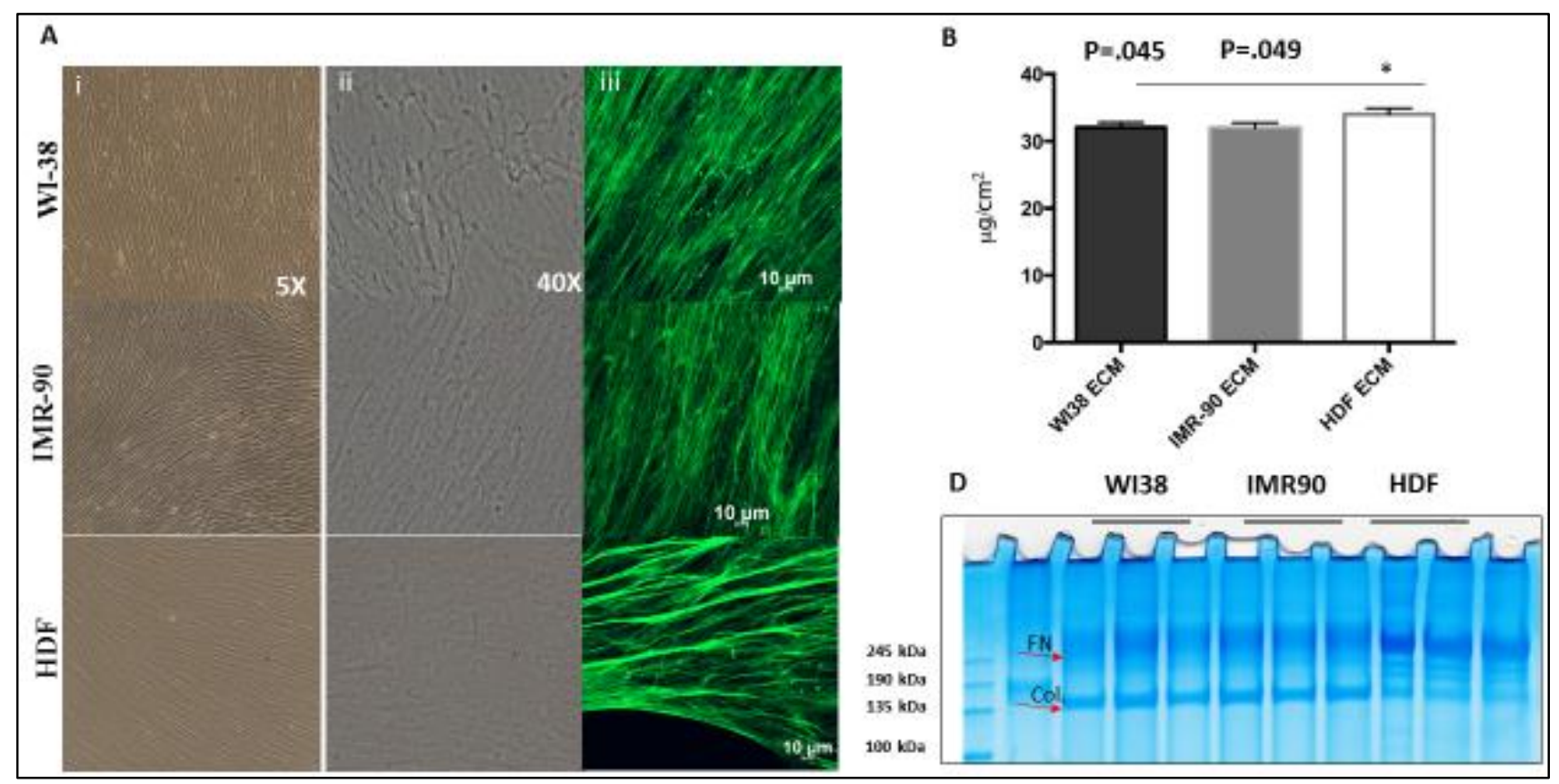

Figure 4-Fibroblasts and their ECM. (Ai) 5X phase contrast microscopy of fibroblasts. (Aii) 40X phase contrast microscopy of decellularized fibroblast-derived ECM. (Aiii) Confocal microscopy of fibroblast-derived ECM with NHS-ester probe. (B) ECM Quantified protein analysis $\left(\mu \mathrm{g} / \mathrm{cm}^{2}\right), \mathrm{N}=3 * \mathrm{p}<.05$ (TABLE VII). (D) SDS PAGE and Colloidal Blue stain of fibroblastderived ECM. $\mathrm{N}=3$.

\section{B. Fibroblast-derived Matrices Alter Lung Cancer Cell Morphology}

The first experiment that was conducted once fibroblast-derived matrices were successfully produced was to determine how cell morphology changes when lung cancer cells 
were grown on human lung-specific matrix, human dermal matrix, or a normal fibronectincoated tissue culture treated dish. Fibronectin-coated dishes were used as a control because it simulates both the traditional 2D cell culture environment as well as having a natural ECM component. After fibroblast extraction and ECM purification, A549, H358, and HPL1D cell lines were seeded onto the fibroblast-derived matrices or FN-coated dish, and then imaged 48 hours later to determine morphology. Observation by phase-contrast microscopy (Figure 5Ai) revealed marked differences in cell shape, especially A549 cells. H358 and HPL1D cells exhibited a slight spindle-shaped morphology. A549 cells showed the biggest change in morphology, thus were analyzed further quantify the change (figure 5B). Phalloidin, a chemical known to have a high specificity for filamentous actin, was used to visualize the cytoskeleton of the cell by confocal microscopy. Simple geometric calculations such as area and perimeter were used to judge cell circularity (Figure 5C). All three fibroblast-derived matrices significantly ( $\mathrm{p}<.05$, $\mathrm{N}=10$ ) pressured A549 cells to form a more elliptical shape, instead of a more circular shape (Circularity $=1$ ), which is exhibited more on fibronectin (Figure 5C). A549 cells on fibronectin have an average circularity value of $.38+/-.04$, while the same cells on WI38, IMR-90, and HDF ECM have average circularity values of $.18+/-.034(\mathrm{p}=.004), .18+/-.038(\mathrm{p}=.0023)$, and $.12+/-$ $.019(\mathrm{p}=.0002)$, respectfully. Cells settled between matrix fibers and elongated according to the direction of the fibers. However, the type of ECM did not have differential effects on cell morphology, suggesting that the type and content of the ECM does not induce morphological change in lung cancer cell lines. Changes in cell morphology can induce drastic alterations in cell processes such as proliferation and migration, thus influencing the fate of the cancer cells. In fact, it has been previously reported that cell shape can influence the metastatic capabilities of 
some cancers (Yin et al., 2013). Cell elongation may contribute to increased cell migration. It is interesting that A549 cells have the most drastic change in morphology, suggesting that this cell line may have altered growth and migration properties, compared to H358 and HPL1D cells.
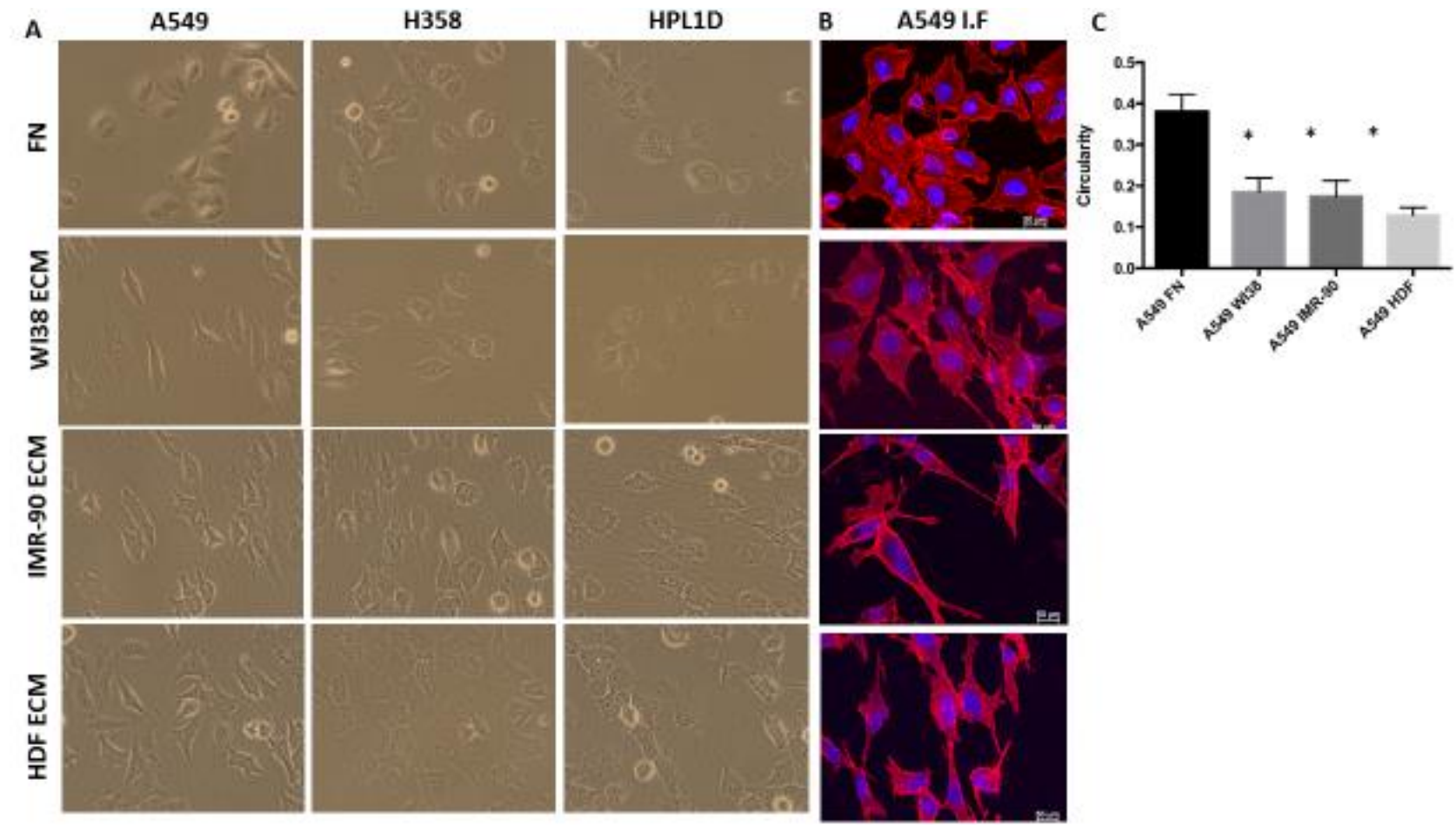

Figure 5- Fibroblast-derived ECM alter Lung Cancer Cell Line Morphology. (A) Phase contrast microscopy photos of A549, H358, and HPL1D cells on FN, WI38 ECM, IMR-90, and HDF ECM. (B) A549 cells on WI38 ECM stained with Phallodin and DAPI. (C) A549 circularity on FN and WI38 ECM. N=10. *, p<.05 (TABLE X)

\section{Fibroblast-derived Matrices Alter Lung cancer Cell Growth}

Next, cell growth alterations due to interaction with the various fibroblast-derived matrices were examined. Even without employing assays to measure cell number and proliferation, it is clear by microscopy that human fibroblast-derived matrices affect cell growth, because there are 
simply fewer cells to observe after several doubling times. To test the hypothesis that lung cancer cells proliferate less when cultured on fibroblast-derived ECM, Alamar Blue ${ }^{\mathrm{TM}}$ and cell-counting assays were used. A549, H358, and HPL1D were seeded onto 12-well plates for Trypan blue ${ }^{\mathrm{TM}}$ cell counting, or 96-well plates for an Alamar Blue ${ }^{\mathrm{TM}}$ assay, and recorded measurements for four consecutive days. Trypan blue $\mathrm{TM}^{\mathrm{TM}}$ is a dye that stains cells with a disrupted cell membrane, thus it only accumulates in dead cells. Alternately, Alamar Blue ${ }^{\mathrm{TM}}$ is a blue dye that gets reduced to a purple fluorescent molecule by oxidative reaction in the electron transport chain. Thus Alamar Blue $^{\mathrm{TM}}$ reduction is directly proportional to cellular metabolism. It is clear that both cell density number (Figure 6A) and subsequent Alamar Blue ${ }^{\mathrm{TM}}$ (Figure 6B) metabolism were attenuated when all cell lines were cultured on all matrices. Cukierman et al. showed that various human epithelial cancers such as breast and colon cancer cell lines grow slower when cultured on mouse fibroblast-derived ECM (Serebriiskii et al., 2008). It is the belief in the field that an increased extracellular matrix presence should enhance cancerous properties. However, this data suggests that fibroblast-derived ECM inhibit the growth of lung cancer cell lines. Interestingly, a recent publication has determined that high mechanical strain induces cell cycle entry mediated by Ecadherin (Benham-Pyle et al., 2015). Therefore, this decreased growth could be due to the altered force the cells experience when cultured on fibroblast-derived matrix. Alternately, perhaps lung cancer cells lines grow slower on fibroblast-derived ECM because the ECM creates a barrier between neighboring cells, thus eliminating cell-cell interactions. Nevertheless, more studies are needed that determine exactly how fibroblast-derived ECM slow down the growth of lung cancer cell lines, compared to the same cells on a fibronectin-coated tissue culture dish. 


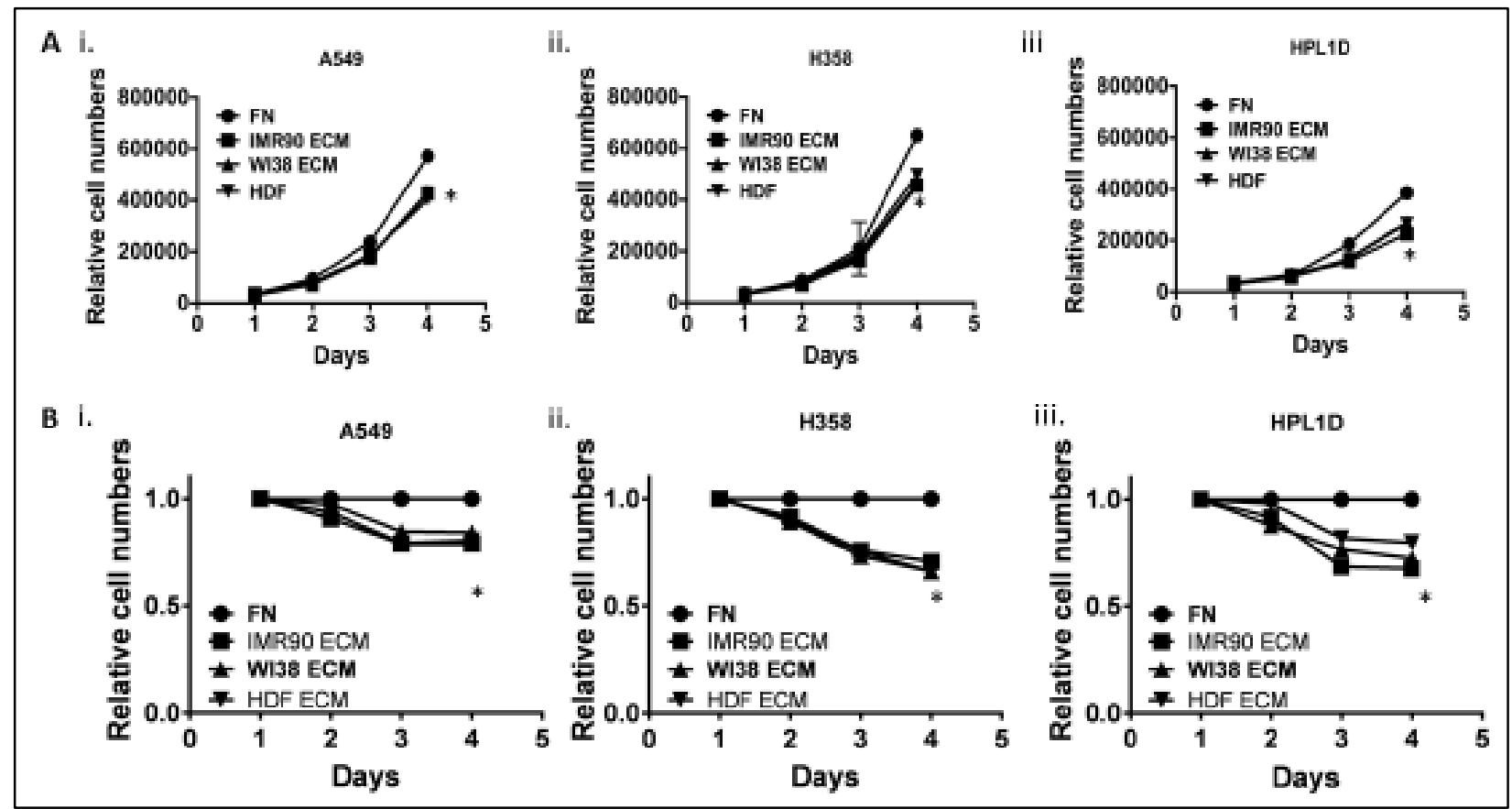

Figure 6- Fibroblast-derived ECM alter Lung Cancer Cell Growth. (A) Manual cell counting. ${ }^{*}, \mathrm{P}<.05$. (Ai) A549 on all three fibroblast-derived ECM (TABLE XI). (Aii) H358 on all three fibroblast-derived ECM (TABLE XII). (Aiii) HPL1D on all fibroblast-derived ECM (TABLE XIII). B: Alamar Blue TM*,P<.05. (Bi) A549 on all three fibroblast-derived ECM. (Bii) H358 on all three fibroblast-derived ECM. (Biii) HPL1D on all fibroblast-derived ECM. N=3. *, Pvalue $<.05$ (TABLE XIV-XVI)

D. Fibroblast-Derived Matrices alter functional protein levels of lung cancer cell lines

To perhaps understand which growth-related signaling pathways are attenuated when A549 cells interact with various fibroblast-derived ECM, western blot analysis was performed. Western blotting is a common analytical technique that uses antibodies to detect specific protein levels in a cell lysate. Here, A549 cells cultured on FN, WI38 ECM, IMR-90 ECM, and HDF 
ECM were lysed, spilling out soluble protein. Antibodies specific for proteins involved in MAPK signaling, Epithelial-to-Mesenchymal Transition (EMT) signaling, as well other proteins known to be involved in cellular proliferation were utilized to help understand why A549 cells have restricted growth when cultured on all fibroblast-derived matrices. Interestingly, many proteins and phosphorylated proteins are decreased at the protein level, as detected by western blot (Figure 7). Phosphorylated MAPK family members such as P38 and P44/42 are decreased when A549 cells are cultured on all fibroblast-derived ECM (Figure 7B). MAPK initiation is known to activate many downstream pathways that affect cell cycle entry and cell growth (Segar et al., 1995). Similarly, AKT, Cyclic-AMP Response Element Binding (CREB) protein, and Mammalian-Target of Rapamycin (MTOR), which are all together involved in several cascades that regulate cell cycle, are decreased when A549 cells are cultured on all fibroblast-derived matrices (Figure 7A and 7B). Also, CDC42, a known cell cycle regulator, and phosphorylated SRC kinase, a known oncogene in lung cancers, are decreased on fibroblast-derived ECM. These data suggest possible effector molecules that are disrupted when A549 cells are cultured on fibroblast-derived ECM, thus providing key insight into the effect of the ECM on lung cancer cell line growth.

As previously stated, metastatic lung cancer is the deadliest and most aggressive form of the disease. EMT is a process initiated by cells in the primary tumor in order to migrate and become metastatic. Biomarkers of EMT are the loss of E-cadherin, and the gain on Vimentin expression in epithelial cancers (Xiao et al., 2010). It is hypothesized that ECM can influence EMT biomarkers, thus inducing cells to undergo EMT. Interestingly, E-cadherin expression is greatly decreased and Vimentin expression is a slightly increased when A549 cells are cultured 
on all fibroblast-derived matrices. These data suggest that fibroblast-derived ECM alter EMT markers of A549 cells, which could induce a more migratory phenotype, thus increasing likelihood of metastasis.

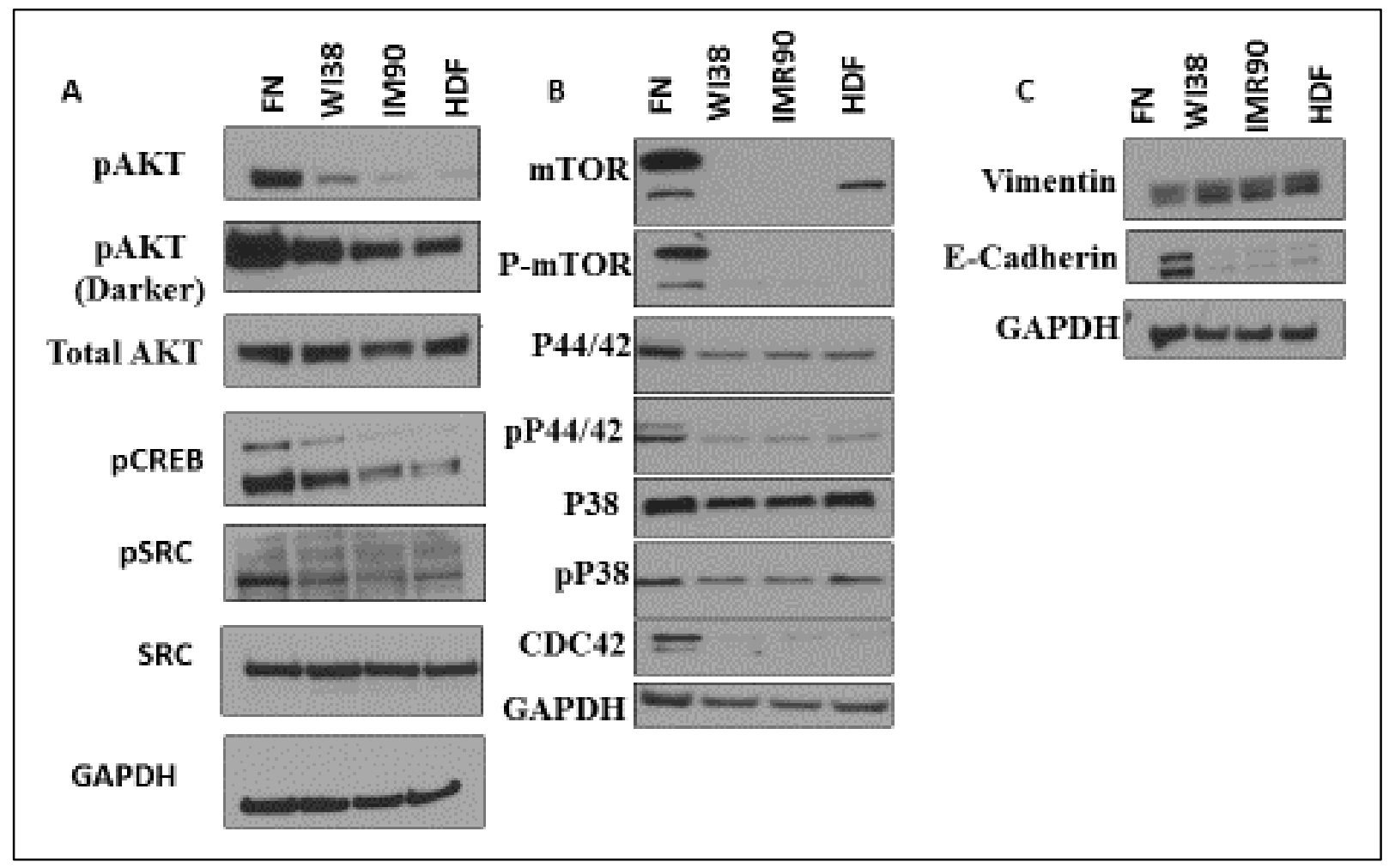

Figure 7- Fibroblast-derived ECM alters Protein Levels of A549 Cells. (A) Western blot of AKT, pAKT, pCREB, pSRC, total SRC, and GAPDH. (B) Western blot of mTOR, PhosphorylatedmTOR, P44/42, Phosphorylated P44/42, p38, Phosphorylated p38, CDC42, and GAPDH. (C) Western blot of Vimentin, E-cadherin, and GAPDH. 


\section{E. Fibroblast Derived Matrices Do not alter Drug Resistance of Lung Cancer Cell Lines}

Cancer cells grown in three dimensions, such as in Matrigel ${ }^{\mathrm{TM}}$, or in a spheroid-forming medium, experience epigenetic changes that alter cancer phenotype. Three dimensional cell culture gives the cell line a TME that influences its response to drug treatment. Similarly, the human TME helps cancer cells evade drug-induced cell death. It was hypothesized that because human lung fibroblast-derived ECM alter lung cancer cell line morphology and growth rates, then it was reasonable to assume drug response would also change. To test this, lung cancer cells cultured on human lung fibroblast-derived ECM were treated with various chemotherapeutic agents often used in the clinic to treat lung cancer patients. Interestingly, culturing A549, H358, and HPL1D cells on WI38 ECM did not alter the dose response of Cisplatin and Gemcitabine (Figure 8A-C), which are common first-line therapies for lung cancer patients. Perhaps these drugs are so cytotoxic that the ECM has little or no effect. However, this model could still be beneficial for future drug studies. For instance, if there is an alteration in a certain drug response on fibroblast-derived ECM, it could provide evidence that the certain therapy is affected by the ECM, which could serve as an indicator of its efficacy in an in vivo setting. 
A

A549

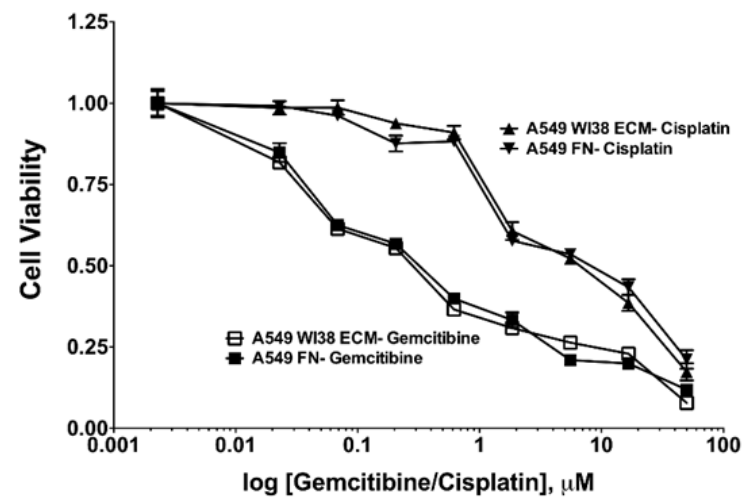

B

H358



C

HPL1D

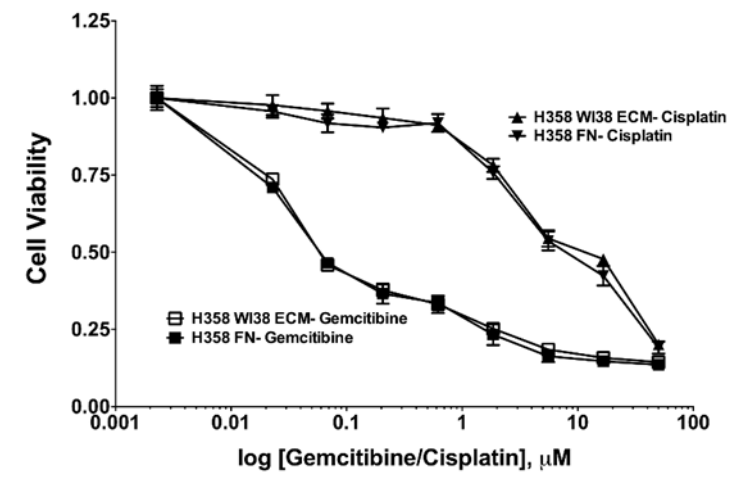


Figure 8- Fibroblast-derived ECM do does not alter drug response to Gemcitabine and Cisplatin. (A) A549 on WI38 ECM. (B) H358 on WI38 ECM. (C) HPL1D on WI38 ECM. N=3. Not significant ( $\mathrm{p}>$.999).

\section{F. Fibroblast Derived Matrices Protect Lung Cancer Cells from Serum Deprivation}

Although the drug response of lung cancer cell lines is not affected by human fibroblastderived ECM, other experiments to test the ability of lung cancer cell lines to survive stressful environments when cultured on ECM, such as serum withdrawal, were explored. Serum deprivation induces cellular apoptosis by mitochondrial outer membrane permealibilzation (MOMP) in colorectal cancer cells (Braun et al., 2011). Although many cancer cells evade apoptosis by inhibiting MOMP, many cancer cell lines cannot survive prolonged exposure to serum-free media. However, little is known about how the ECM affects serum dependability. It is hypothesized that proteins and growth factors present in the fibroblast-derived ECM can sustain lung cancer cells in an otherwise nutrient-free environment. To test the effects of serum depletion on cells on and off fibroblast-derived ECM, cells were seeded in complete media for 24 hours to allow cells to adhere, media was then removed and cells were washed with PBS, and replenished with serum-free media. Observation by phase contrast microscopy revealed that 48 hours after the removal of serum from the media, there are more A549 cells on ECM compared 
to a fibronectin dish, suggesting that the ECM supports cell adhesion and perhaps growth in the absence of serum (Figure 9D). To determine the difference between cell growth on ECM and fibronectin, Alamar Blue ${ }^{\mathrm{TM}}$ metabolism was followed each day. All lung cancer cell lines cultured on both human lung and human dermal fibroblast-derived ECM showed an increase in relative viable cells compared to the same cell lines grown on fibronectin plates (Figure 9A, 9B, and 9C). A549 survive serum deprivation the best by Alamar Blue ${ }^{\mathrm{TM}}$ (figure 9A), until day 4. HPL1D and H358 cells also tolerated serum withdrawal well until day 4 (Figure 9A, 9B). However, The ECM was not able to sustain cell viability without serum past four days. Perhaps this is due to degradation of the ECM and its growth factors by the lung cancer cell lines. Also, A549 cells cultured on ECM did not change morphology when cultured in serum-free media (Figure 9B), whereas as A549 cells on Fibronectin-coated dish appeared rounded and unhealthy (Figure 9A). Upon western blot analysis, it was clear that fibroblast-derived ECM rescues serum deprivation-induced apoptosis by evading p21 expression and by upregulating BCL-xL expression (Figure 9F). p21, is a cyclin-dependent kinase inhibitor that is known to promote cellcycle arrest and apoptosis in serum-free conditions (Braun et al., 2011). Interestingly, BCL-xL, an anti-apoptotic protein that protects cells against apoptosis, is slightly increased when A549 cells are cultured on fibroblast-derived ECM with and without serum (figure 9F), thus suggesting it plays a role in the survival of A549 cells in serum-free conditions. These results suggest that the ECM is capable of providing a cell-survival stimulus when the plethora of growth factors and nutrients available in FBS are absent. This observation might be important in understanding how lung adenocarcinoma cells survive in the inner-most core of a solid tumor, where nutrients, as well as oxygen, from the blood supply are scarce. 

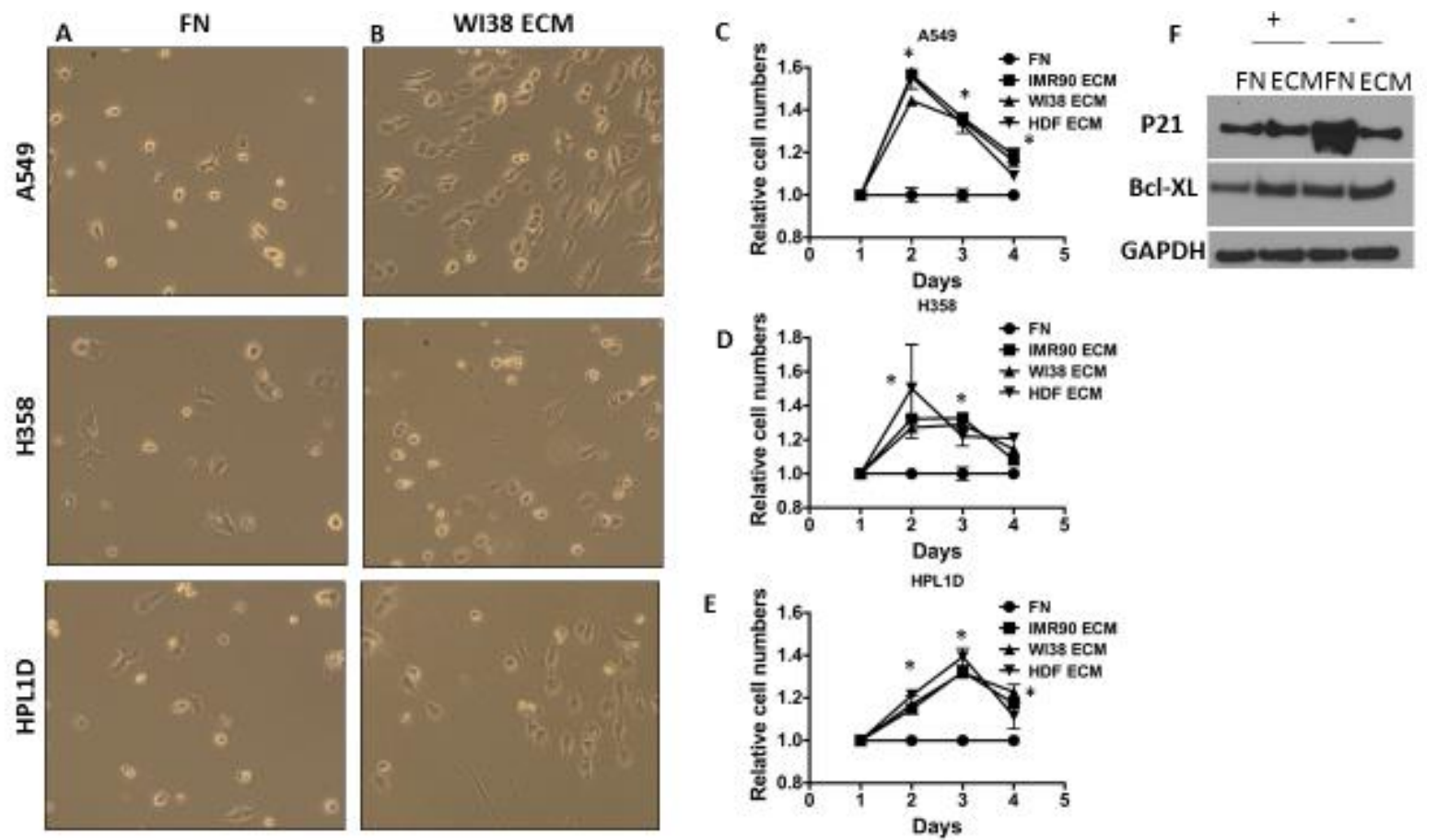

Figure 9- Fibroblast-derived ECM Protects Lung Cancer Cell Lines from Serum Deprivation. (A) A549, H358, and HPL1D cells on fibronectin in serum-free media for 48 hours. (B) A549, H358, and HPL1D cells on WI38 ECM in serum-free media for 48 hours. (C) Relative cell growth of A549 cells. (D) Relative cell growth of H358 cells. (E) Relative cell growth of HPL1D cells. (F) Western blot of serum deprived cells after 48 hours. *,p<.05 (TABLE IV-VI)

G. Fibroblast-Derived Matrices Change mRNA levels of Various Genes in Lung Cancer Cells

It is clear that human lung fibroblast-derived ECM alters many processes that influence behaviors like morphology, growth, and serum-deprivation survival. However, little is known about how fibroblast-derived ECM alters the regulation of gene transcription. Transcription 
regulation is an extremely important process that influences cellular phenotypes. Therefore, an experiment was designed to determine the effect of gene transcription when A549 and H358 cells interact with human fibroblast-derived ECM. A microarray was used to determine the difference of messenger-RNA (mRNA) copy number when lung cancer cell lines were cultured on fibroblast-derived ECM. MRNA is the result of a transcribed gene, awaiting ribosome entry to be translated into an amino acid sequence, which is then folded to the proper native protein structure. Although mRNA quantity does not directly dictate functional protein quantity, it is directly connected with how much DNA is transcribed. To test the change in mRNA copy number in lung cancer on human fibroblast-derived ECM, A549 and H358 cell lines were cultured for 48 hours on WI-38 ECM, IMR-90 ECM, and Fibronectin-coated plastic. Briefly, RNA was extracted, converted to DNA, labeled, hybridized, and scanned for hybridization quantification. Data was then analyzed by Sabine Waigel and the UofL genomics core facility. A heat map was generated (Figure 10A) to show an unrefined interpretation of each gene probe intensity that was significant changed compared to a fibronectin-coated dish (P-value $<.05$ and fold change greater than 1.5). It is clear by examining the heat map that there are many gene probes that differ in expression induced by fibroblast-derived ECM. In total, 182 target sequences, which corresponded to 114 gene changes, were shared between both cells lines on both fibroblast-derived ECM compared to fibronectin. Affected Gene IDs were uploaded into Metacore $^{\mathrm{TM}}$ for Gene Ontology (GO) analysis. Metacore ${ }^{\mathrm{TM}} \mathrm{GO}$ process analysis identifies canonical and non-canonical pathways that are likely to be affected by a cluster of significantly changed genes. Top ranked potentially affected pathways include complement-mediated immunity, cytoskeletal remodeling, and ECM remodeling (Figure 10B). Interestingly, 87 of 
these significant gene changes were down-regulated, and only 27 were upregulated. Many downregulated genes coded for proteins that constitute the extracellular matrix, suggesting that when cells are in contact with adequate ECM, they decrease transcription of genes that code for ECM proteins such as fibrinogen alpha, fibrinogen beta, collagen type 4, collagen type 5, and villin (Table 2). Also, MMP7, which is a protease that degrades Collagen and Fibronectin, is also down-regulated. The most down-regulated gene, LGALS2 belongs to a family of galectins, which can serve as interacting proteins with ECM proteins and can be deregulated in some cancers, including lung cancer (Liu et al., 2005; Buttery et al., 2004). Also, several genes that regulate the complement-mediated immunity pathway, such as $\mathrm{C} 3, \mathrm{C} 1 \mathrm{~S}$, and bradykinin, are down-regulated when both lung cancer cell lines are cultured on WI38 and IMR90 ECM (Table 2). Complement-mediated immunity pathways have been shown to be activated in lung cancer (Pio et al., 2014). Interestingly, Galectin expression affects also complement activation (Pio et al., 2013). Up-regulated genes include NT5E, IL-8, KCNMA1, BCAT1, ASNS, stanniocalcin-2, and PSAT1 (Table 3). Interestingly. IL-8 is known to promote angiogenesis' thus supporting previous research by Patricia Soucy, suggesting a role for ECM in angiogenesis (Luppi et al., 2007; Soucy et al., 2015; Soucy et al., 2009). NT5E, which is also known as ecto-5'nucleotidase, has been shown to be upregulated in lung and breast cancers where it decreases patient survival rates by attenuating immune responses and promoting environments for vascularization and metastasis ( Zhang et al., 2010; Jin et al., 2010). KCNMA1, a gene that reported four probes that had significant expression changes, codes for a protein that complexes to form potassium and calcium ion channels (Table 3). KCNMA1 ion channels have been shown to be more present in metastatic breast cancer cells but little is known of its role in lung cancer 
(Khaitan et al., 2009). The ECM is a key player in the initiation of breast cancer cells into metastasis. This result that KCNMA1 mRNA is increased when lung cancer cells are cultured on fibroblast-derived ECM might suggest that ECM can induce KCNMA1 to play a protumorigenic role in lung cancer cells. Similarly, stanniocalcin-2, a gene that had three probes reported from the microarray data, also plays a role calcium regulation, and is also overexpressed in lung cancer and impairs a poor prognosis (Na et al., 2015). ASNS, BCAT1, and PSAT1 all code for enzymes that regulate amino acid synthesis, thus directly affecting cell growth and proliferation. These microarray data reveals the complex mechanisms that the ECM can regulate within lung cancer cells. Thus providing strong evidence that Fibroblast-derived ECM can potentiate the phenotype of lung cancer cell lines.

A

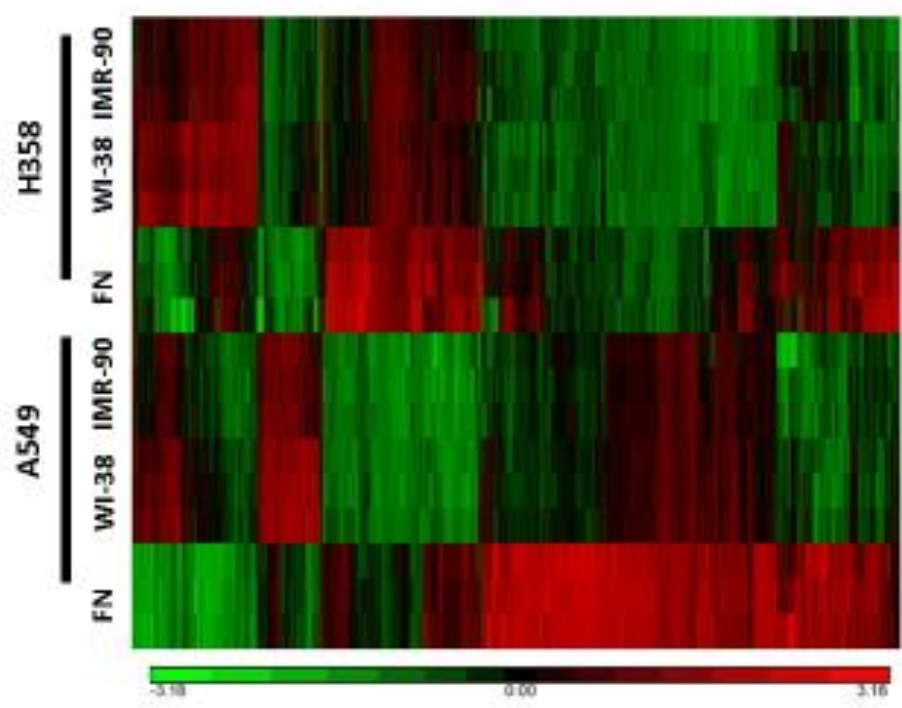

B

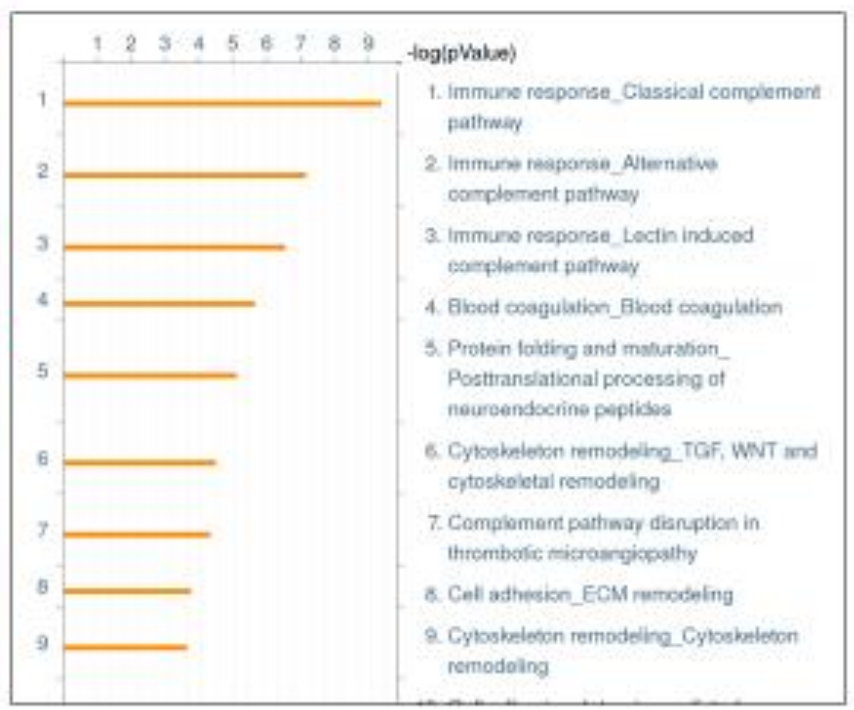

Figure 10- Fibroblast-derived ECM alters mRNA profile of A549 and H358 Cells. (A) heat map of common significant (fold change >1.5 and P-Value<.05). (B) Gene Ontology (GO) Processes. 
To validate the microarray results, primers were designed to bind only to the mRNA region of various hits from the microarray data. Separate samples were analyzed to confirm the results. QPCR analysis (figure 11) revealed that indeed, mRNA that was altered on the microarray are also being altered in separate biological replicates. Further, the direction of the fold changes were shared between microarray data and qPCR, thus giving confidence in the highly sensitive microarray data.

TABLE II

COMMON RANKED DOWN-REGULATED GENES BETWEEN A549 AND H358

CELLS ON WI38 AND IMR-90 ECM

\begin{tabular}{|c|c|}
\hline Gene Symbol & Fold Change \\
\hline LGALS2 & -20.280 \\
\hline PDZK1 /// PDZK1P1 & -10.4226 \\
\hline KCNJ16 & -6.6045 \\
\hline MGAM & -6.26486 \\
\hline FGB & -5.69714 \\
\hline FGB & -5.60535 \\
\hline FGG & -5.5835 \\
\hline SLC23A1 & -5.33021 \\
\hline CORO2A & $-5,31961$ \\
\hline FGB & -5.2152 \\
\hline CORO2A & -5.18083 \\
\hline TM4SF20 & -5.16027 \\
\hline FGA & -5.1169 \\
\hline MGAM & -5.00299 \\
\hline PDZK1 /// PDZK1P1 & $-4,80629$ \\
\hline SEBOX /// VTN & -4.70113 \\
\hline TM4SF20 & -4.53339 \\
\hline SLPI & -4.29842 \\
\hline HGD & -4.25802 \\
\hline COLAA4 & -4.14101 \\
\hline LCN2 & -3.91643 \\
\hline FGA & -3.90491 \\
\hline VIL1 & -3.8627 \\
\hline
\end{tabular}

\begin{tabular}{|l|r|}
\hline Gene Symbol & \multicolumn{1}{l}{ Fold Change } \\
\hline AQP3 & -3.72207 \\
\hline TC2N & -3.60948 \\
\hline COL12A1 & -3.34803 \\
\hline BAAT & -3.33715 \\
\hline CDH1 & -3.2636 \\
\hline RND1 & -3.20194 \\
\hline CP & -3.0807 \\
\hline COL4A4 & -3.00602 \\
\hline KRT4 & -2.95014 \\
\hline CP & -2.9092 \\
\hline SLC17A3 & -2.90152 \\
\hline DDC & -2.87355 \\
\hline BCAS1 & -2.84022 \\
\hline RND1 & -2.7561 \\
\hline BDKRB2 & -2.72445 \\
\hline COL5A1 & -2.66928 \\
\hline ELMO1 & -2.3403 \\
\hline C3 & -2.29049 \\
\hline MMP7 & -2.25888 \\
\hline CLDN2 & -2.24846 \\
\hline C1S & -2.19828 \\
\hline CXXC5 & -1.80768 \\
\hline MYLK & -1.79433 \\
\hline DNMT3B & -1.62753 \\
\hline
\end{tabular}


TABLE III

COMMON RANKED UP-REGULATED GENES BETWEEN A549 AND H358 CELLS ON WI38 AND IMR-90 ECM

\begin{tabular}{|c|c|}
\hline Gene Symbol & Fold Change \\
\hline NTSE & 3.07708 \\
\hline IL8 & 2.88492 \\
\hline TMEM158 & 2.68639 \\
\hline NTSE & 2.60764 \\
\hline KCNMA1 & 2.53873 \\
\hline KCNMA1 & 2.4901 \\
\hline STC2 & 2.44285 \\
\hline BCAT1 & 2.39524 \\
\hline KCNMA1 & 2.3891 \\
\hline BCAT1 & 2.3149 \\
\hline ASNS & 2.27585 \\
\hline STC2 & 2.2733 \\
\hline KCNMA1 & 2.2436 \\
\hline CDCP1 & 2.23108 \\
\hline ASNS & 2.20114 \\
\hline STC2 & 2.18055 \\
\hline BCAT1 & 2.16265 \\
\hline ASNS & 2.13614 \\
\hline FAM129A & 2.09353 \\
\hline PHLDA1 & 2.08875 \\
\hline ASNS & 2.07363 \\
\hline
\end{tabular}

\begin{tabular}{|c|c|}
\hline Gene Symbol & Fold Change \\
\hline FAM129A & 2.09353 \\
\hline PHLDA1 & 2.08875 \\
\hline ASNS & 2.07363 \\
\hline SMOX & 1.8889 \\
\hline CHAC1 & 1.88397 \\
\hline SMOX & 1.84901 \\
\hline SMOX & 1.83655 \\
\hline PSAT1 & 1.83508 \\
\hline CDCP1 & 1.79694 \\
\hline PSAT1 & 1.7723 \\
\hline PHGDH & 1.76288 \\
\hline PSAT1 & 1.75183 \\
\hline STMN3 & 1.74967 \\
\hline SMOX & 1.73798 \\
\hline PSAT1 & 1.7237 \\
\hline PSAT1 & 1.68015 \\
\hline PSAT1 & 1.67523 \\
\hline CTSL1 & 1.66385 \\
\hline SFRP1 & 1.64401 \\
\hline ID4 & 1.61766 \\
\hline RAB39B & 1.58386 \\
\hline
\end{tabular}

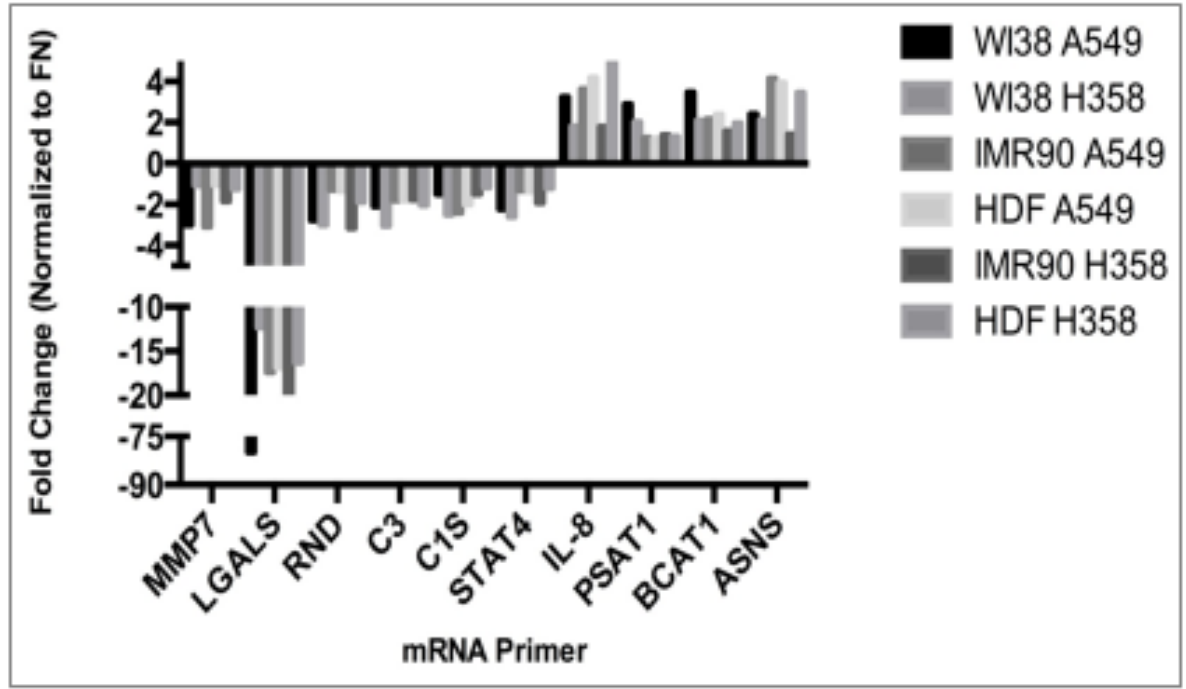

Figure 11- Fold Change of mRNA by Quantitative qPCR 


\section{H. Fibroblast-Derived Matrices can Induce Lung Cancer Cells to Migrate}

In order to test how human fibroblast-derived ECM affects cellular migration, which is a critical mechanism that lung cancer cells utilize to invade and metastasize, a simple experiment was designed employing a trans-well chamber assay. A trans-well chamber is a tissue culture device that has $0.8 \mu \mathrm{m}$ pores that allow actively migrating cells to pass through to the bottom. Trans-well chambers are used to model migratory and invasive properties of cells. Many cancer cell biologists employ such chambers to test whether migration is altered following a given treatment. Here, trans-well chambers were used as a substrate to grow ECM, which was then used to recruit lung cancer cells. It is hypothesized that human fibroblast-derived ECM could act as a chemoattractant that could recruit lung cancer cell lines to its side of the Trans-well chamber. Clearly, all fibroblast-derived ECM act as a chemoattractant for a549 cells and induce them to migrate across the chamber (figure 12A). Upon counting, Three times the number of A549 cells were migratory when fibroblast-derived ECM was present, compared to fibronectin. Also, it is clear visually by Hemotoxylin and Eosin staining that more A549 migrated to the fibroblast-derived ECM (Figure 12B). Cell migration is an important process that affects both wound healing and cancer progression. In cancer, local as well as distal ECM environments are equally as important in understanding cancer cell invasion and metastasis. Therefore, incorporation of fibroblast-derived ECM into trans-well migration could provide researchers with a better model to study cancer cell migration. 
A

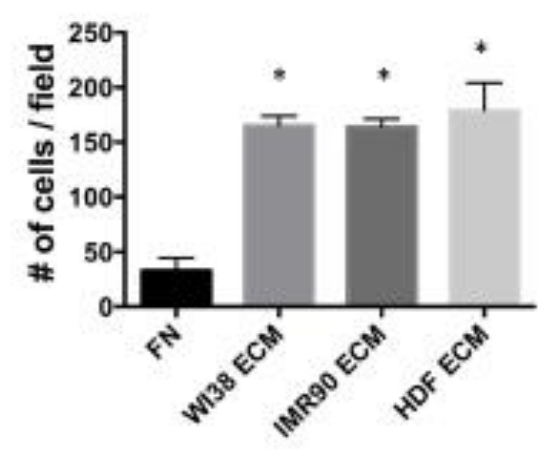

B

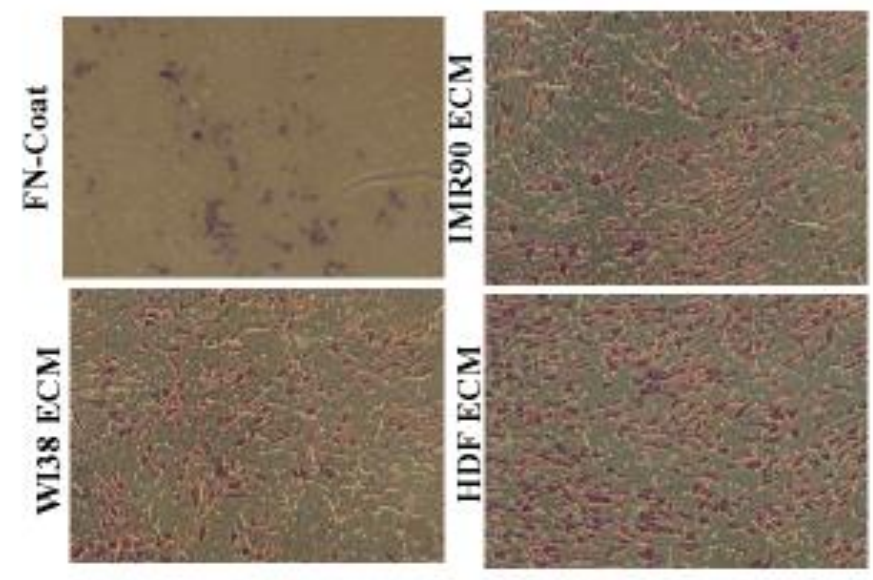

Figure 12- Fibroblast-derived ECM alter Cell Migration of Lung Cancer Cell Lines in a Trans-well Chamber. (A) Average migratory cells per field (4 fields). *, p<.05 (TABLE XIX)

It is clear from microscopic observation that lung cancer cell lines on fibroblast-derived ECM do not grow in large clusters like the same cells on fibronectin. It was postulated that cells grown on the $3 \mathrm{D}$ fibers of the ECM exhibit migration along the fibers, thus spreading the cells apart from each other. To test this type of migration, A549, H358 and HPL1D cells were seeded onto fibroblast-derived matrices and after 24 hours, and transferred into a live cell microscopy chamber for time lapse imaging (Figure 13). Time lapse shows that cells grown on fibroblastderived matrix exhibit more migration than on a fibronectin-coated dish. A549, H358, and HPL1D cells all migrated farther distances on fibroblast-derived ECM than on Fibronectin (Figure 13A). Cells were tracked for between 4 and 8 hours (Figure 13A). It is clear that A549, H358 and HPL1D cells migrate farther distances in 4-8 hours when cultured on fibroblastderived ECM. To characterize this, directionality (D/d) (Figure 13B) is calculated to determine the linearity of the directional migration (Figure 13C). Evidently, A549, H358, and HPL1D cell 
lines exhibited a more directional migration on fibroblast-derived ECM compared to control. Also, it is clear by calculating distance traveled by time traveled that the velocity of the cells on fibroblast-derived ECM is greater than the same cells on fibronectin (Figure 13D). It appears that when the lung cancer cell lines interact with a fiber, they travel along that fiber only, rarely migrating towards adjacent fibers. This result will be important for future cell migration studies, encouraging researchers to use ECM that are highly aligned. Cell migration properties are highly adopted in lung cancer cells, which allow them to invade accessible organs. These data indicate that the interaction between fibroblast-derived ECM and lung cancer cell lines induce a migratory phenotype. It is interesting that fibroblast-derived ECM alters EMT properties, thus suggesting that the ECM plays a role in EMT induction. Therefore, fibroblast-derived matrices should be used in the future to study ECM-induced EMT.

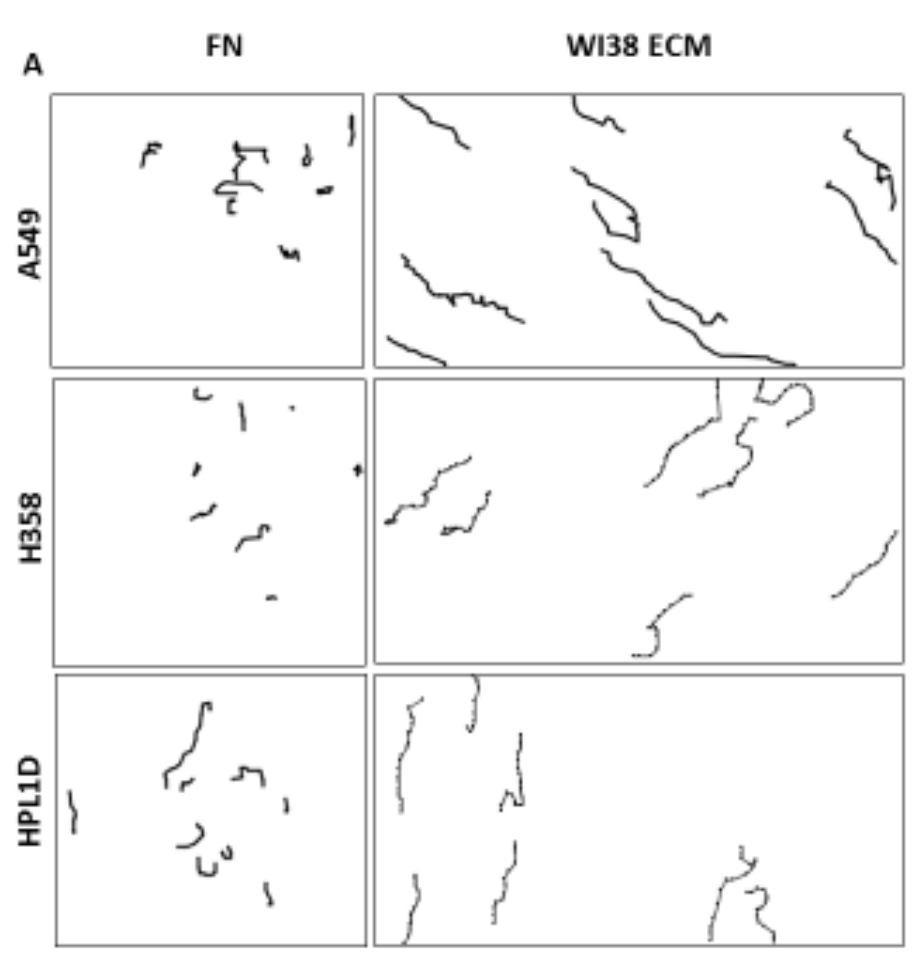

B

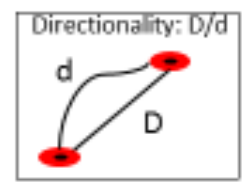

C

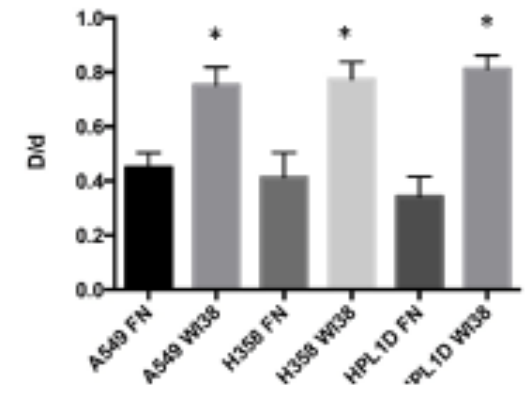

D

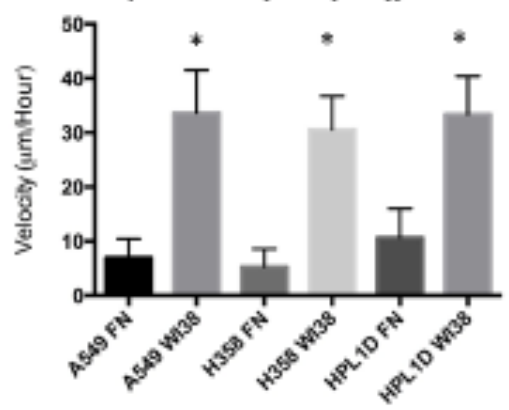


Figure 13- Fibroblast-derived ECM induce Directional Migration. (A) Resultant timelapse tracks of A549, H358, and HPL1D on WI38 ECM. (B) Depiction of Directionality= D/d. (C) Calculated Directionality A549 p=.033, H358 p=.0067, HPL1D p=.0002). N=7. (D) Average velocity of migrated cells ( $\mu \mathrm{m} /$ hour) $\mathrm{N}=7$. A549, H358, HPL1D $\mathrm{p}<.0001$.

\section{Fibroblast-derived ECM increase Subcutaneous Xenograft Tumor Formation in Mice}

Previously, researchers have mixed cancer cells with Matrigel $^{\mathrm{TM}}$ and implant them into the subcutaneous tissue of mice to study tumor development with an extracellular matrix component (Bao et al., 1994). To determine if fibroblast-derived matrix proteins could illicit a similar pro-tumorigenic response, fibroblast-derived ECM was scraped in ice cold PBS and mixed with cells. The same ECM-to-cell ratio of 26,000 cells $/ \mathrm{cm}^{2}$ that was used in vitro was used in vivo. A549 cells and matrix orA549 cells without matrix were injected into the subcutaneous tissue of 3 month old NRG mice and let incubate for 60 days. NRG mice are a new breed of mice that harbor mutations in NOD, RAG, and Interleukin-2 gamma receptor, which eliminates the immune system of $\mathrm{T}$ and $\mathrm{B}$ cells, thus allowing for xenografts without an immune response. A549 cells cultured with the scraped fibroblast-derived ECM grew larger tumors by calculated volume than a549 cells with PBS (figure 14). However, these data are not statically significant, with a p-value of 0.07 (Figure 14C) Further, tumors with ECM showed increased mass (Figure 14D). Although A549 cells mixed with ECM formed larger tumors, hemotoxylin and Eosin staining revealed little differences in the morphology of the tumors (Figure 14Ei and 14Eii). A pathologist might be able to determine differences in the tumor sections, but little is 
noticeable to the untrained eye. Although fibroblast-derived ECM decreased lung cancer cell line growth in vitro, it appears that they it enhance tumor formation in vivo. It could be that in the in vivo experiments, the native architecture of the fibroblast-derived ECM that is present in vitro is absent, thus allowing for unrestricted growth. Further, the same survival signals that the lung cancer cell lines exploit from the ECM in vitro when cultured in serum free conditions may be providing growth signals in A549 xenograft. These data are important in elucidating the role of ECM architecture, as well as its composition in cancer signaling.
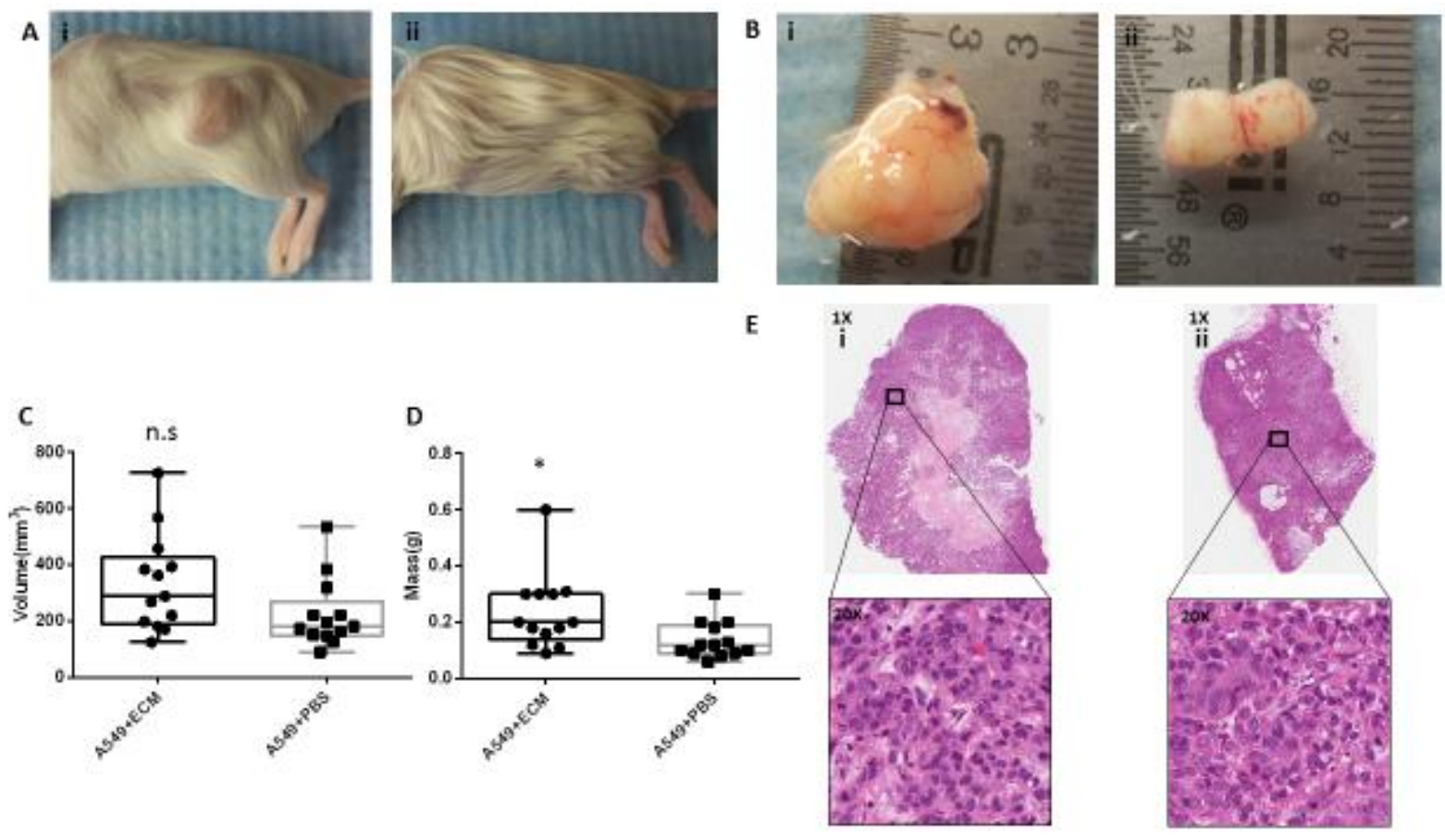

Figure 14- Fibroblast-derived ECM Increase Subcutaneous Tumor Formation of A549 Cells in Mice. Ai: in vivo A549 with ECM Xenograft. Aii: in vivo A549 with PBS Xenograft. Bi: Picture of removed tumor with ECM. Bi: Picture of removed tumor with PBS. C: Calculated volumes of A549 xenografts with and without ECM ( $\mathrm{p}=.07)$ D: Measured mass ( $\mathrm{g}$ ) of excised 
tumors. Ei: 1X picture of A549 Xenograft with ECM with 20X expanded view. Eii: 1X picture of A549 Xenograft with PBS with 20X expanded view. N=13. *,p=.026.

\section{Conclusions and Future Directions}

This work shows that human fibroblast-derived extracellular matrix alters cell morphology, cell growth, proliferation, mRNA expression, functional protein expression, and migration properties of the A549, H358, and HPL1D lung cancer cell lines. It is clear that when cultured on human fibroblast-derived ECM, lung cancer cell lines have less activated MAPK protein expression as well as mTOR and cell cycle regulating pathways, which might contribute to their attenuated growth. Also, lung cancers have altered expression of ECM protein-coding and complement-mediated immunity genes, thus affecting many downstream pathways. As discovered by western blot, lung cancer cell lines also develop an EMT phenotype, which could be responsible for their increased migration. Interestingly, ECM harvested from different fibroblast cell lines originating from different human tissues did not have a noticeable effect in this work. Perhaps a less harsh decellularization technique will leave behind a more unique ECM, thus allowing researchers to better mimic the natural ECM. This work is significant because it provides further evidence that the extracellular matrix has a strong effect on the phenotype of lung cancer cells, which needs to be further studied to successfully treat the entire tumor microenvironment.

In future work, scientists will attempt to alter the influence of the extracellular matrix on lung cancer cells. For instance, the age of an organism significantly increases the probability of cancer and it is known that cancer vulnerability can be influenced by the extracellular matrix. 
Fibroblast-derived matrix procured from old and young fibroblasts could differentially regulate the growth and migration properties of lung cancer cells. Also, future researchers could successfully overexpress oncogenes or knock down tumor suppressors in human lung or dermal fibroblasts and determine their matrix components and subsequent effect on lung cancer cell lines. Further, to expand research in different focus groups, future researchers could examine how the ECM affects leukemia cells with regards to homing and drug resistance. This future work could provide valuable knowledge of the feedback mechanism that exists between cancer and its extracellular matrix.

V. Appendix

TABLE IV

A549 SERUM DEPRIVATION STATISTICAL ANALYSIS

\begin{tabular}{|c|c|c|c|c|}
\hline A549 Serum deprivation & & & & \\
\hline Number of families & 4 & & & \\
\hline $\begin{array}{l}\text { Number of comparisons per } \\
\text { family }\end{array}$ & 6 & & & \\
\hline Alpha & 0.05 & & & \\
\hline $\begin{array}{l}\text { Tukey's multiple } \\
\text { comparisons test }\end{array}$ & $\begin{array}{l}\text { Mean } \\
\text { Diff. }\end{array}$ & $95 \%$ CI of diff. & Summary & $\begin{array}{l}\text { Adjusted P } \\
\text { Value }\end{array}$ \\
\hline \multicolumn{5}{|l|}{ Row 1} \\
\hline FN vs. IMR90 ECM & 0 & $\begin{array}{l}-0.09736 \text { to } \\
0.09736\end{array}$ & $\mathrm{~ns}$ & $>0.9999$ \\
\hline FN vs. WI38 ECM & $\begin{array}{r}1.99 \mathrm{E}- \\
08\end{array}$ & $\begin{array}{l}-0.09736 \text { to } \\
0.09736\end{array}$ & $\mathrm{~ns}$ & $>0.9999$ \\
\hline FN vs. HDF ECM & 0 & $\begin{array}{l}-0.09736 \text { to } \\
0.09736\end{array}$ & $\mathrm{~ns}$ & $>0.9999$ \\
\hline IMR90 ECM vs. WI38 ECM & $\begin{array}{r}1.99 \mathrm{E}- \\
08\end{array}$ & $\begin{array}{l}-0.09736 \text { to } \\
0.09736\end{array}$ & $\mathrm{~ns}$ & $>0.9999$ \\
\hline IMR90 ECM vs. HDF ECM & 0 & $\begin{array}{l}-0.09736 \text { to } \\
0.09736\end{array}$ & $\mathrm{~ns}$ & $>0.9999$ \\
\hline WI38 ECM vs. HDF ECM & $-2 \mathrm{E}-08$ & $\begin{array}{l}-0.09736 \text { to } \\
0.09736\end{array}$ & $\mathrm{~ns}$ & $>0.9999$ \\
\hline
\end{tabular}




\begin{tabular}{|c|c|c|c|c|}
\hline \multirow{2}{*}{\multicolumn{5}{|c|}{ Row 2}} \\
\hline & & & & \\
\hline FN vs. IMR90 ECM & -0.566 & $\begin{array}{l}-0.6634 \text { to }- \\
0.4687\end{array}$ & $* * * *$ & $<0.0001$ \\
\hline FN vs. WI38 ECM & -0.4437 & $\begin{array}{l}-0.5411 \text { to }- \\
0.3463\end{array}$ & $* * * *$ & $<0.0001$ \\
\hline FN vs. HDF ECM & -0.5542 & $\begin{array}{l}-0.6516 \text { to }- \\
0.4569\end{array}$ & $* * * *$ & $<0.0001$ \\
\hline IMR90 ECM vs. WI38 ECM & 0.1223 & $\begin{array}{l}0.02496 \text { to } \\
0.2197\end{array}$ & ** & 0.0093 \\
\hline IMR90 ECM vs. HDF ECM & 0.01178 & $\begin{array}{l}-0.08558 \text { to } \\
0.1091\end{array}$ & ns & 0.9876 \\
\hline WI38 ECM vs. HDF ECM & -0.1105 & $\begin{array}{l}-0.2079 \text { to }- \\
0.01318\end{array}$ & $*$ & 0.0211 \\
\hline \multicolumn{5}{|l|}{ Row 3} \\
\hline FN vs. IMR90 ECM & -0.3626 & $\begin{array}{l}-0.4600 \text { to }- \\
0.2653\end{array}$ & $* * * *$ & $<0.0001$ \\
\hline FN vs. WI38 ECM & -0.3496 & $\begin{array}{l}-0.4470 \text { to }- \\
0.2523\end{array}$ & $* * * *$ & $<0.0001$ \\
\hline FN vs. HDF ECM & -0.3315 & $\begin{array}{l}-0.4289 \text { to }- \\
0.2342\end{array}$ & $* * * *$ & $<0.0001$ \\
\hline IMR90 ECM vs. WI38 ECM & 0.01299 & $\begin{array}{l}-0.08437 \text { to } \\
0.1103\end{array}$ & ns & 0.9835 \\
\hline IMR90 ECM vs. HDF ECM & 0.03112 & $\begin{array}{l}-0.06624 \text { to } \\
0.1285\end{array}$ & $\mathrm{~ns}$ & 0.8222 \\
\hline WI38 ECM vs. HDF ECM & 0.01813 & $\begin{array}{l}-0.07923 \text { to } \\
0.1155\end{array}$ & $\overline{\mathrm{ns}}$ & 0.9574 \\
\hline \multicolumn{5}{|l|}{ Row 4} \\
\hline FN vs. IMR90 ECM & -0.1861 & $\begin{array}{l}-0.2834 \text { to }- \\
0.08870\end{array}$ & $* * * *$ & $<0.0001$ \\
\hline FN vs. WI38 ECM & -0.159 & $\begin{array}{l}-0.2563 \text { to }- \\
0.06161\end{array}$ & $* * *$ & 0.0006 \\
\hline FN vs. HDF ECM & 0.08953 & $\begin{array}{l}-0.1869 \text { to } \\
0.007827\end{array}$ & $\mathrm{~ns}$ & 0.0805 \\
\hline IMR90 ECM vs. WI38 ECM & 0.02709 & $\begin{array}{l}-0.07027 \text { to } \\
0.1244\end{array}$ & $\mathrm{~ns}$ & 0.8744 \\
\hline IMR90 ECM vs. HDF ECM & 0.09652 & $\begin{array}{l}-0.0008332 \text { to } \\
0.1939\end{array}$ & ns & 0.0527 \\
\hline WI38 ECM vs. HDF ECM & 0.06944 & $\begin{array}{l}-0.02792 \text { to } \\
0.1668\end{array}$ & $\mathrm{~ns}$ & 0.2351 \\
\hline
\end{tabular}


TABLE V

H358 SERUM DEPRIVATION STATISTICAL ANALYSIS

\begin{tabular}{|c|c|c|c|c|}
\hline H358 Serum Deprivation & & & & \\
\hline Number of families & 4 & & & \\
\hline $\begin{array}{l}\text { Number of comparisons per } \\
\text { family }\end{array}$ & 6 & & & \\
\hline Alpha & 0.05 & & & \\
\hline $\begin{array}{l}\text { Tukey's multiple comparisons } \\
\text { test }\end{array}$ & $\begin{array}{l}\text { Mean } \\
\text { Diff. }\end{array}$ & $95 \%$ CI of diff. & Significant? & $\begin{array}{l}\text { Adjusted P } \\
\text { Value }\end{array}$ \\
\hline Row 1 & & & & \\
\hline FN vs. IMR90 ECM & $-2 \mathrm{E}-08$ & -0.2692 to 0.2692 & No & $>0.9999$ \\
\hline FN vs. WI38 ECM & $-2 \mathrm{E}-08$ & -0.2692 to 0.2692 & No & $>0.9999$ \\
\hline FN vs. HDF ECM & $2 \mathrm{E}-08$ & -0.2692 to 0.2692 & No & $>0.9999$ \\
\hline IMR90 ECM vs. WI38 ECM & 0 & -0.2692 to 0.2692 & No & $>0.9999$ \\
\hline IMR90 ECM vs. HDF ECM & $4 \mathrm{E}-08$ & -0.2692 to 0.2692 & No & $>0.9999$ \\
\hline WI38 ECM vs. HDF ECM & 4E-08 & -0.2692 to 0.2692 & No & $>0.9999$ \\
\hline Row 2 & & & & \\
\hline FN vs. IMR90 ECM & -0.3225 & $\begin{array}{l}-0.5918 \text { to }- \\
0.05327\end{array}$ & Yes & 0.0139 \\
\hline FN vs. WI38 ECM & -0.271 & $\begin{array}{l}-0.5402 \text { to }- \\
0.001707\end{array}$ & Yes & 0.0481 \\
\hline FN vs. HDF ECM & -0.5012 & -0.7705 to -0.2320 & Yes & $<0.0001$ \\
\hline IMR90 ECM vs. WI38 ECM & 0.05156 & -0.2177 to 0.3208 & No & 0.954 \\
\hline IMR90 ECM vs. HDF ECM & -0.1787 & $\begin{array}{l}-0.4480 \text { to } \\
0.09053\end{array}$ & No & 0.2927 \\
\hline WI38 ECM vs. HDF ECM & -0.2303 & $\begin{array}{l}-0.4995 \text { to } \\
0.03897\end{array}$ & No & 0.1153 \\
\hline Row 3 & & & & \\
\hline FN vs. IMR90 ECM & -0.3275 & $\begin{array}{l}-0.5967 \text { to }- \\
0.05824\end{array}$ & Yes & 0.0122 \\
\hline FN vs. WI38 ECM & -0.2891 & $\begin{array}{l}-0.5584 \text { to }- \\
0.01988\end{array}$ & Yes & 0.0315 \\
\hline FN vs. HDF ECM & -0.2195 & $\begin{array}{l}-0.4887 \text { to } \\
0.04979\end{array}$ & No & 0.1427 \\
\hline IMR90 ECM vs. WI38 ECM & 0.03836 & -0.2309 to 0.3076 & No & 0.9801 \\
\hline IMR90 ECM vs. HDF ECM & 0.108 & -0.1612 to 0.3773 & No & 0.6998 \\
\hline
\end{tabular}




\begin{tabular}{|c|c|c|c|c|}
\hline WI38 ECM vs. HDF ECM & 0.06967 & -0.1996 to 0.3389 & No & 0.8959 \\
\hline \multicolumn{5}{|l|}{ Row 4} \\
\hline FN vs. IMR90 ECM & -0.0809 & -0.3501 to 0.1883 & No & 0.8473 \\
\hline FN vs. WI38 ECM & -0.1447 & -0.4140 to 0.1245 & No & 0.4748 \\
\hline FN vs. HDF ECM & -0.2083 & $\begin{array}{l}-0.4776 \text { to } \\
0.06093\end{array}$ & No & 0.176 \\
\hline IMR90 ECM vs. WI38 ECM & -0.0638 & -0.3331 to 0.2054 & No & 0.9174 \\
\hline IMR90 ECM vs. HDF ECM & -0.1274 & -0.3966 to 0.1418 & No & 0.5807 \\
\hline WI38 ECM vs. HDF ECM & -0.0636 & -0.3328 to 0.2057 & No & 0.9183 \\
\hline
\end{tabular}

TABLE VI

HPL1D SERUM DEPRIVATION STATISTICAL ANALYSIS

\begin{tabular}{|c|c|c|c|c|}
\hline HPL1D Serum Deprivation & & & & \\
\hline Number of families & 4 & & & \\
\hline $\begin{array}{l}\text { Number of comparisons per } \\
\text { family }\end{array}$ & 6 & & & \\
\hline Alpha & 0.05 & & & \\
\hline $\begin{array}{l}\text { Tukey's multiple } \\
\text { comparisons test }\end{array}$ & $\begin{array}{l}\text { Mean } \\
\text { Diff. }\end{array}$ & $95 \%$ CI of diff. & Significant? & $\begin{array}{l}\text { Adjusted P } \\
\text { Value }\end{array}$ \\
\hline Row 1 & & & & \\
\hline FN vs. IMR90 ECM & $-2 \mathrm{E}-08$ & $\begin{array}{l}-0.1039 \text { to } \\
0.1039\end{array}$ & No & $>0.9999$ \\
\hline FN vs. WI38 ECM & $-2 \mathrm{E}-08$ & $\begin{array}{l}-0.1039 \text { to } \\
0.1039\end{array}$ & No & $>0.9999$ \\
\hline FN vs. HDF ECM & $-2 \mathrm{E}-08$ & $\begin{array}{l}-0.1039 \text { to } \\
0.1039\end{array}$ & No & $>0.9999$ \\
\hline IMR90 ECM vs. WI38 ECM & 0 & $\begin{array}{l}-0.1039 \text { to } \\
0.1039\end{array}$ & No & $>0.9999$ \\
\hline IMR90 ECM vs. HDF ECM & 0 & $\begin{array}{l}-0.1039 \text { to } \\
0.1039\end{array}$ & No & $>0.9999$ \\
\hline WI38 ECM vs. HDF ECM & 0 & $\begin{array}{l}-0.1039 \text { to } \\
0.1039\end{array}$ & No & $>0.9999$ \\
\hline Row 2 & & & & \\
\hline FN vs. IMR90 ECM & -0.1468 & -0.2508 to - & Yes & 0.003 \\
\hline
\end{tabular}




\begin{tabular}{|c|c|c|c|c|}
\hline & & 0.04287 & & \\
\hline FN vs. WI38 ECM & -0.1686 & $\begin{array}{l}-0.2726 \text { to }- \\
0.06466\end{array}$ & Yes & 0.0006 \\
\hline FN vs. HDF ECM & -0.2119 & $\begin{array}{l}-0.3159 \text { to }- \\
0.1080\end{array}$ & Yes & $<0.0001$ \\
\hline IMR90 ECM vs. WI38 ECM & -0.0218 & $\begin{array}{l}-0.1257 \text { to } \\
0.08215\end{array}$ & No & 0.9408 \\
\hline IMR90 ECM vs. HDF ECM & -0.06514 & $\begin{array}{l}-0.1691 \text { to } \\
0.03881\end{array}$ & No & 0.3414 \\
\hline WI38 ECM vs. HDF ECM & -0.04334 & $\begin{array}{l}-0.1473 \text { to } \\
0.06061\end{array}$ & No & 0.6743 \\
\hline \multicolumn{5}{|l|}{ Row 3} \\
\hline FN vs. IMR90 ECM & -0.3222 & $\begin{array}{l}-0.4261 \text { to }- \\
0.2182\end{array}$ & Yes & $<0.0001$ \\
\hline FN vs. WI38 ECM & -0.3179 & $\begin{array}{l}-0.4218 \text { to }- \\
0.2139\end{array}$ & Yes & $<0.0001$ \\
\hline FN vs. HDF ECM & -0.3933 & $\begin{array}{l}-0.4973 \text { to }- \\
0.2894\end{array}$ & Yes & $<0.0001$ \\
\hline IMR90 ECM vs. WI38 ECM & 0.004302 & $\begin{array}{l}-0.09964 \text { to } \\
0.1082\end{array}$ & No & 0.9995 \\
\hline IMR90 ECM vs. HDF ECM & -0.07113 & $\begin{array}{l}-0.1751 \text { to } \\
0.03282\end{array}$ & No & 0.2678 \\
\hline WI38 ECM vs. HDF ECM & -0.07543 & $\begin{array}{l}-0.1794 \text { to } \\
0.02852\end{array}$ & No & 0.2219 \\
\hline \multicolumn{5}{|l|}{ Row 4} \\
\hline FN vs. IMR90 ECM & -0.1735 & $\begin{array}{l}-0.2774 \text { to }- \\
0.06951\end{array}$ & Yes & 0.0004 \\
\hline FN vs. WI38 ECM & -0.2279 & $\begin{array}{l}-0.3319 \text { to }- \\
0.1240\end{array}$ & Yes & $<0.0001$ \\
\hline FN vs. HDF ECM & -0.1141 & $\begin{array}{l}-0.2181 \text { to }- \\
0.01020\end{array}$ & Yes & 0.027 \\
\hline IMR90 ECM vs. WI38 ECM & -0.05446 & $\begin{array}{l}-0.1584 \text { to } \\
0.04949\end{array}$ & No & 0.4968 \\
\hline IMR90 ECM vs. HDF ECM & 0.05931 & $\begin{array}{l}-0.04463 \text { to } \\
0.1633\end{array}$ & No & 0.423 \\
\hline WI38 ECM vs. HDF ECM & 0.1138 & $\begin{array}{l}0.009828 \text { to } \\
0.2177\end{array}$ & Yes & 0.0276 \\
\hline
\end{tabular}

TABLE VII

ECM PROTEIN STATISTICAL ANALYSIS 


\begin{tabular}{|c|c|c|c|c|}
\hline ECM Protein & & & & \\
\hline Number of families & 1 & & & \\
\hline $\begin{array}{l}\text { Number of comparisons per } \\
\text { family }\end{array}$ & 3 & & & \\
\hline Alpha & 0.05 & & & \\
\hline $\begin{array}{l}\text { Tukey's multiple } \\
\text { comparisons test }\end{array}$ & $\begin{array}{l}\text { Mean } \\
\text { Diff. }\end{array}$ & $95 \%$ CI of diff. & Summary & $\begin{array}{l}\text { Adjusted P } \\
\text { Value }\end{array}$ \\
\hline $\begin{array}{l}\text { WI38 ECM vs. IMR-90 } \\
\text { ECM }\end{array}$ & 0.04534 & -1.902 to 1.992 & $\mathrm{~ns}$ & 0.9972 \\
\hline WI38 ECM vs. HDF ECM & -1.953 & $\begin{array}{l}-3.900 \text { to }- \\
0.005657\end{array}$ & $*$ & 0.0495 \\
\hline IMR-90 ECM vs. HDF ECM & -1.998 & $\begin{array}{l}-3.945 \text { to }- \\
0.05100\end{array}$ & $*$ & 0.0453 \\
\hline
\end{tabular}

TABLE VIII

TIME-LAPSE STATISTICAL ANALYSIS

\begin{tabular}{|l|r|l|l|l|}
\hline Time-lapse Migration Velocity & 1 & & & \\
\hline Number of families & 15 & & & \\
\hline Number of comparisons per family & 0.05 & & & \\
\hline Alpha & & & & \\
\hline & $\begin{array}{l}\text { Mean } \\
\text { Diff. }\end{array}$ & $95 \%$ CI of diff. & Summary & $\begin{array}{l}\text { Adjusted } \\
\text { P Value }\end{array}$ \\
\hline Tukey's multiple comparisons test & & & & \\
\hline & -26.64 & -35.96 to -17.32 & $* * * *$ & $<0.0001$ \\
\hline A549 FN vs. A549 WI38 & 1.734 & -7.590 to 11.06 & ns & 0.993 \\
\hline A549 FN vs. H358 FN & -3.643 & -12.97 to 5.680 & ns & 0.8454 \\
\hline A549 FN vs. HPL1D FN & 28.37 & 19.05 to 37.70 & $* * * *$ & $<0.0001$ \\
\hline A549 WI38 vs. H358 FN & 3.07 & -6.254 to 12.39 & ns & 0.918 \\
\hline A549 WI38 vs. H358 WI38 & 23 & 13.67 to 32.32 & $* * * *$ & $<0.0001$ \\
\hline A549 WI38 vs. HPL1D FN & 0.2967 & -9.027 to 9.620 & ns & $>0.9999$ \\
\hline A549 WI38 vs. HPL1D WI38 & -25.3 & -34.63 to -15.98 & $* * * *$ & $<0.0001$ \\
\hline H358 FN vs. H358 WI38 & -5.377 & -14.70 to 3.947 & & ns \\
\hline H358 FN vs. HPL1D FN & -2.773 & -12.10 to 6.550 & & 0.5187 \\
\hline H358 WI38 vs. HPL1D WI38 & & & & 0.9453 \\
\hline
\end{tabular}




\begin{tabular}{|l|l|l|l|l|}
\hline HPL1D FN vs. HPL1D WI38 & -22.7 & -32.02 to -13.38 & $* * * *$ & $<0.0001$ \\
\hline & & & & \\
\hline & & & & \\
\hline & & & & \\
\hline & & & & \\
\hline & & & & \\
\hline
\end{tabular}

TABLE IX

DIRECTIONALITY STATISTICAL ANALYSIS

\begin{tabular}{|c|c|c|c|c|c|}
\hline Directionality & & & & & \\
\hline Number of families & 1 & & & & \\
\hline $\begin{array}{l}\text { Number of comparisons } \\
\text { per family }\end{array}$ & 15 & & & & \\
\hline Alpha & 0.05 & & & & \\
\hline $\begin{array}{l}\text { Tukey's multiple } \\
\text { comparisons test }\end{array}$ & $\begin{array}{l}\text { Mean } \\
\text { Diff. }\end{array}$ & $\begin{array}{l}\text { 95\% CI of } \\
\text { diff. }\end{array}$ & $\begin{array}{l}\text { Significant } \\
?\end{array}$ & \begin{tabular}{|l} 
Summar \\
$\mathrm{y}$
\end{tabular} & $\begin{array}{l}\text { Adjusted P } \\
\text { Value }\end{array}$ \\
\hline A549 FN vs. A549 WI38 & -0.3031 & $\begin{array}{l}-0.5907 \text { to }- \\
0.01558\end{array}$ & Yes & $*$ & 0.0336 \\
\hline A549 FN vs. H358 FN & 0.03643 & $\begin{array}{l}-0.2511 \text { to } \\
0.3240\end{array}$ & No & $\mathrm{ns}$ & 0.9989 \\
\hline A549 FN vs. H358 WI38 & -0.3244 & $\begin{array}{l}-0.6120 \text { to }- \\
0.03687\end{array}$ & Yes & * & 0.019 \\
\hline A549 FN vs. HPL1D FN & 0.1072 & $\begin{array}{l}-0.1804 \text { to } \\
0.3947\end{array}$ & No & ns & 0.8735 \\
\hline $\begin{array}{l}\text { A549 FN vs. HPL1D } \\
\text { WI38 }\end{array}$ & -0.3624 & $\begin{array}{l}-0.6499 \text { to }- \\
0.07483\end{array}$ & Yes & ** & 0.0064 \\
\hline A549 WI38 vs. H358 FN & 0.3396 & $\begin{array}{l}0.05201 \text { to } \\
0.6271\end{array}$ & Yes & * & 0.0124 \\
\hline $\begin{array}{l}\text { A549 WI38 vs. H358 } \\
\text { WI38 }\end{array}$ & -0.02129 & $\begin{array}{l}-0.3088 \text { to } \\
0.2663\end{array}$ & No & ns & $>0.9999$ \\
\hline A549 WI38 vs. HPL1D & 0.4103 & 0.1227 to & Yes & *** & 0.0015 \\
\hline
\end{tabular}




\begin{tabular}{|l|r|l|l|l|r|}
\hline FN & & 0.6978 & & & \\
\hline A549 WI38 vs. HPL1D & -0.05925 & -0.3468 to & No & ns & 0.9893 \\
WI38 & & 0.2283 & & & 0.0067 \\
\hline H358 FN vs. H358 WI38 & -0.3609 & $\begin{array}{l}-0.6484 \text { to }- \\
0.07330\end{array}$ & Yes & $* *$ & 0.9765 \\
\hline H358 FN vs. HPL1D FN & 0.07072 & $\begin{array}{l}-0.2168 \text { to } \\
0.3583\end{array}$ & No & ns & 0.0021 \\
\hline H358 FN vs. HPL1D & -0.3988 & -0.6864 to - & Yes & $* *$ & 0.0008 \\
WI38 & & 0.1113 & & & \\
\hline H358 WI38 vs. HPL1D & 0.4316 & 0.1440 to & Yes & $* * *$ & 0.9987 \\
FN & & 0.7191 & & & 0.0002 \\
\hline H358 WI38 vs. HPL1D & -0.03796 & -0.3255 to & No & ns & \\
WI38 & & 0.2496 & & & \\
\hline HPL1D FN vs. HPL1D & -0.4695 & -0.7571 to - & Yes & $* * *$ & \\
WI38 & & 0.1820 & & &
\end{tabular}

TABLE $X$

CIRCULARITY STATISTICAL ANALYSIS

\begin{tabular}{|l|r|l|l|l|l|}
\hline Cell Circularity & & & & & \\
\hline Number of families & 1 & & & & \\
\hline $\begin{array}{l}\text { Number of comparisons per } \\
\text { family }\end{array}$ & 6 & & & & \\
\hline Alpha & 0.05 & & & & \\
\hline & $\begin{array}{l}\text { Mean } \\
\text { Diff. }\end{array}$ & $\begin{array}{l}\text { 95\% CI of } \\
\text { diff. }\end{array}$ & $\begin{array}{l}\text { Significant } \\
?\end{array}$ & $\begin{array}{l}\text { Summar } \\
\text { y }\end{array}$ & $\begin{array}{l}\text { Adjusted P } \\
\text { Value }\end{array}$ \\
\hline $\begin{array}{l}\text { Tukey's multiple } \\
\text { comparisons test }\end{array}$ & 0.196 & $\begin{array}{l}0.05046 \text { to } \\
0.3414\end{array}$ & Yes & $* *$ & 0.0043 \\
\hline A549 FN vs. A549 WI38 & 0.2074 & $\begin{array}{l}0.06186 \text { to } \\
0.3528\end{array}$ & Yes & $* *$ & 0.0023 \\
\hline A549 FN vs. A549 IMR-90 & & & & & \\
\hline
\end{tabular}




\begin{tabular}{|l|l|l|l|l|l|}
\hline A549 FN vs. A549 HDF & 0.2528 & $\begin{array}{l}0.1073 \text { to } \\
0.3982\end{array}$ & Yes & $* * *$ & 0.0002 \\
\hline
\end{tabular}

TABLE XI

A549 CELL COUNTING STATISTICAL ANALYSIS

\begin{tabular}{|c|c|c|c|c|}
\hline A549 Count & & & & \\
\hline \multicolumn{5}{|c|}{ Within each row, compare columns (simple effects within rows) } \\
\hline Number of families & 4 & & & \\
\hline $\begin{array}{l}\text { Number of comparisons per } \\
\text { family }\end{array}$ & 6 & & & \\
\hline Alpha & 0.05 & & & \\
\hline $\begin{array}{l}\text { Tukey's multiple comparisons } \\
\text { test }\end{array}$ & $\begin{array}{l}\text { Mean } \\
\text { Diff. }\end{array}$ & $95 \%$ CI of diff. & Significant? & $\begin{array}{l}\text { Adjusted P } \\
\text { Value }\end{array}$ \\
\hline \multicolumn{5}{|l|}{ Row 1} \\
\hline FN vs. IMR90 ECM & 2667 & $\begin{array}{l}-43697 \text { to } \\
49030\end{array}$ & No & 0.9986 \\
\hline FN vs. WI38 ECM & 6000 & $\begin{array}{l}-40364 \text { to } \\
52364\end{array}$ & No & 0.9849 \\
\hline FN vs. HDF & 1000 & $\begin{array}{l}-45364 \text { to } \\
47364\end{array}$ & No & $>0.9999$ \\
\hline IMR90 ECM vs. WI38 ECM & 3333 & $\begin{array}{l}-43030 \text { to } \\
49697\end{array}$ & No & 0.9973 \\
\hline IMR90 ECM vs. HDF & -1667 & $\begin{array}{l}-48030 \text { to } \\
44697\end{array}$ & No & 0.9997 \\
\hline WI38 ECM vs. HDF & -5000 & $\begin{array}{l}-51364 \text { to } \\
41364\end{array}$ & No & 0.9911 \\
\hline \multicolumn{5}{|l|}{ Row 2} \\
\hline FN vs. IMR90 ECM & 15667 & $\begin{array}{l}-30697 \text { to } \\
62030\end{array}$ & No & 0.7967 \\
\hline FN vs. WI38 ECM & 21333 & $\begin{array}{l}-25030 \text { to } \\
67697\end{array}$ & No & 0.6026 \\
\hline FN vs. HDF & 14667 & $\begin{array}{l}-31697 \text { to } \\
61030\end{array}$ & No & 0.8266 \\
\hline IMR90 ECM vs. WI38 ECM & 5667 & $\begin{array}{l}-40697 \text { to } \\
52030\end{array}$ & No & 0.9872 \\
\hline IMR90 ECM vs. HDF & -1000 & $\begin{array}{l}-47364 \text { to } \\
45364\end{array}$ & No & $>0.9999$ \\
\hline
\end{tabular}




\begin{tabular}{|c|c|c|c|c|}
\hline WI38 ECM vs. HDF & -6667 & $\begin{array}{l}-53030 \text { to } \\
39697\end{array}$ & No & 0.9796 \\
\hline \multicolumn{5}{|l|}{ Row 3} \\
\hline FN vs. IMR90 ECM & 51667 & 5303 to 98030 & Yes & 0.0243 \\
\hline FN vs. WI38 ECM & 60000 & $\begin{array}{l}13636 \text { to } \\
106364\end{array}$ & Yes & 0.0071 \\
\hline FN vs. HDF & 50000 & 3636 to 96364 & Yes & 0.0306 \\
\hline IMR90 ECM vs. WI38 ECM & 8333 & $\begin{array}{l}-38030 \text { to } \\
54697\end{array}$ & No & 0.9614 \\
\hline IMR90 ECM vs. HDF & -1667 & $\begin{array}{l}-48030 \text { to } \\
44697\end{array}$ & No & 0.9997 \\
\hline WI38 ECM vs. HDF & -10000 & $\begin{array}{l}-56364 \text { to } \\
36364\end{array}$ & No & 0.9361 \\
\hline \multicolumn{5}{|l|}{ Row 4} \\
\hline FN vs. IMR90 ECM & 143333 & $\begin{array}{l}96970 \text { to } \\
189697\end{array}$ & Yes & $<0.0001$ \\
\hline FN vs. WI38 ECM & 136667 & $\begin{array}{l}90303 \text { to } \\
183030\end{array}$ & Yes & $<0.0001$ \\
\hline FN vs. HDF & 165000 & $\begin{array}{l}118636 \text { to } \\
211364\end{array}$ & Yes & $<0.0001$ \\
\hline IMR90 ECM vs. WI38 ECM & -6667 & $\begin{array}{l}-53030 \text { to } \\
39697\end{array}$ & No & 0.9796 \\
\hline IMR90 ECM vs. HDF & 21667 & $\begin{array}{l}-24697 \text { to } \\
68030\end{array}$ & No & 0.5905 \\
\hline WI38 ECM vs. HDF & 28333 & $\begin{array}{l}-18030 \text { to } \\
74697\end{array}$ & No & 0.3631 \\
\hline
\end{tabular}

TABLE XII

H358 CELL COUNTING STATISTICAL ANALYSIS

\begin{tabular}{|l|r|l|l|l|}
\hline H358 Count & & & & \\
\hline Number of families & 4 & & & \\
\hline $\begin{array}{l}\text { Number of comparisons per } \\
\text { family }\end{array}$ & 6 & & & \\
\hline Alpha & 0.05 & & & \\
\hline & & $95 \%$ CI of diff. & Significant? & $\begin{array}{l}\text { Adjusted P } \\
\text { Value }\end{array}$ \\
\hline $\begin{array}{l}\text { Tukey's multiple } \\
\text { comparisons test }\end{array}$ & Mean Diff. & & \\
\hline & & & & \\
\hline
\end{tabular}




\begin{tabular}{|c|c|c|c|c|}
\hline Row 1 & & -97833 to 105833 & No & 0.9996 \\
\hline FN vs. IMR90 ECM & 4000 & -99833 to 103833 & No & $>0.9999$ \\
\hline FN vs. WI38 ECM & 2000 & -96833 to 106833 & No & 0.9991 \\
\hline FN vs. HDF & 5000 & -103833 to 99833 & No & $>0.9999$ \\
\hline IMR90 ECM vs. WI38 ECM & -2000 & $\begin{array}{l}-100833 \text { to } \\
102833\end{array}$ & No & $>0.9999$ \\
\hline IMR90 ECM vs. HDF & 1000 & -98833 to 104833 & No & 0.9998 \\
\hline WI38 ECM vs. HDF & 3000 & & & \\
\hline Row 2 & & -85333 to 118333 & No & 0.9712 \\
\hline FN vs. IMR90 ECM & 16500 & -90833 to 112833 & No & 0.9911 \\
\hline FN vs. WI38 ECM & 11000 & -92333 to 111333 & No & 0.9942 \\
\hline FN vs. HDF & 9500 & -107333 to 96333 & No & 0.9989 \\
\hline IMR90 ECM vs. WI38 ECM & -5500 & -108833 to 94833 & No & 0.9977 \\
\hline IMR90 ECM vs. HDF & -7000 & $\begin{array}{l}-103333 \text { to } \\
100333\end{array}$ & No & $>0.9999$ \\
\hline WI38 ECM vs. HDF & -1500 & & & \\
\hline Row 3 & & -56062 to 147604 & No & 0.6204 \\
\hline FN vs. IMR90 ECM & 45771 & -70062 to 133604 & No & 0.8324 \\
\hline FN vs. WI38 ECM & 31771 & -85062 to 118604 & No & 0.9699 \\
\hline FN vs. HDF & 16771 & -115833 to 87833 & No & 0.982 \\
\hline IMR90 ECM vs. WI38 ECM & -14000 & -130833 to 72833 & No & 0.8667 \\
\hline IMR90 ECM vs. HDF & -29000 & -116833 to 86833 & No & 0.9781 \\
\hline WI38 ECM vs. HDF & -15000 & & & \\
\hline Row 4 & & 93167 to 296833 & Yes & $<0.0001$ \\
\hline FN vs. IMR90 ECM & 195000 & 83167 to 286833 & Yes & 0.0001 \\
\hline FN vs. WI38 ECM & 185000 & 53167 to 256833 & Yes & 0.0013 \\
\hline FN vs. HDF & 155000 & -111833 to 91833 & No & 0.9933 \\
\hline IMR90 ECM vs. WI38 ECM & -10000 & -141833 to 61833 & No & 0.7133 \\
\hline IMR90 ECM vs. HDF & -40000 & -131833 to 71833 & No & 0.8547 \\
\hline
\end{tabular}

TABLE XIII

HPL1D CELL COUNTING STATISTICAL ANALYSIS

\begin{tabular}{|l|r|l|l|l|l|}
\hline HPL1D Count & & & & & \\
\hline Number of families & 4 & & & & \\
\hline $\begin{array}{l}\text { Number of comparisons per } \\
\text { family }\end{array}$ & 6 & & & & \\
\hline Alpha & 0.05 & & & & \\
\hline
\end{tabular}




\begin{tabular}{|c|c|c|c|c|c|}
\hline $\begin{array}{l}\text { Tukey's multiple } \\
\text { comparisons test }\end{array}$ & $\begin{array}{l}\text { Mean } \\
\text { Diff. }\end{array}$ & $\begin{array}{l}\text { 95\% CI of } \\
\text { diff. }\end{array}$ & $\begin{array}{l}\text { Significant } \\
?\end{array}$ & $\begin{array}{l}\text { Summar } \\
\mathrm{y}\end{array}$ & $\begin{array}{l}\text { Adjusted P } \\
\text { Value }\end{array}$ \\
\hline \multicolumn{6}{|l|}{ Row 1} \\
\hline FN vs. IMR90 ECM & -500 & $\begin{array}{l}-20871 \text { to } \\
19871\end{array}$ & No & ns & 0.9999 \\
\hline FN vs. WI38 ECM & 4000 & $\begin{array}{l}-16371 \text { to } \\
24371\end{array}$ & No & $\mathrm{ns}$ & 0.9506 \\
\hline FN vs. HDF & -1000 & $\begin{array}{l}-21371 \text { to } \\
19371\end{array}$ & No & $\mathrm{ns}$ & 0.9991 \\
\hline IMR90 ECM vs. WI38 ECM & 4500 & $\begin{array}{l}-15871 \text { to } \\
24871\end{array}$ & No & $\mathrm{ns}$ & 0.9318 \\
\hline IMR90 ECM vs. HDF & -500 & $\begin{array}{l}-20871 \text { to } \\
19871\end{array}$ & No & ns & 0.9999 \\
\hline WI38 ECM vs. HDF & -5000 & $\begin{array}{l}-25371 \text { to } \\
15371\end{array}$ & No & $\mathrm{ns}$ & 0.9094 \\
\hline \multicolumn{6}{|l|}{ Row 2} \\
\hline FN vs. IMR90 ECM & 8000 & $\begin{array}{l}-12371 \text { to } \\
28371\end{array}$ & No & ns & 0.7135 \\
\hline FN vs. WI38 ECM & 9000 & $\begin{array}{l}-11371 \text { to } \\
29371\end{array}$ & No & ns & 0.6331 \\
\hline FN vs. HDF & 2000 & $\begin{array}{l}-18371 \text { to } \\
22371\end{array}$ & No & $\mathrm{ns}$ & 0.9933 \\
\hline IMR90 ECM vs. WI38 ECM & 1000 & $\begin{array}{l}-19371 \text { to } \\
21371\end{array}$ & No & ns & 0.9991 \\
\hline IMR90 ECM vs. HDF & -6000 & $\begin{array}{l}-26371 \text { to } \\
14371\end{array}$ & No & $\mathrm{ns}$ & 0.8548 \\
\hline WI38 ECM vs. HDF & -7000 & $\begin{array}{l}-27371 \text { to } \\
13371\end{array}$ & No & $\mathrm{ns}$ & 0.7885 \\
\hline \multicolumn{6}{|l|}{ Row 3} \\
\hline FN vs. IMR90 ECM & 67000 & $\begin{array}{l}46629 \text { to } \\
87371\end{array}$ & Yes & $* * * *$ & $<0.0001$ \\
\hline FN vs. WI38 ECM & 55500 & $\begin{array}{l}35129 \text { to } \\
75871\end{array}$ & Yes & $* * * *$ & $<0.0001$ \\
\hline FN vs. HDF & 57500 & $\begin{array}{l}37129 \text { to } \\
77871\end{array}$ & Yes & $* * * *$ & $<0.0001$ \\
\hline IMR90 ECM vs. WI38 ECM & -11500 & $\begin{array}{l}-31871 \text { to } \\
8871\end{array}$ & No & ns & 0.4323 \\
\hline IMR90 ECM vs. HDF & -9500 & -29871 to & No & $\mathrm{ns}$ & 0.5921 \\
\hline
\end{tabular}




\begin{tabular}{|l|r|l|l|l|l|}
\hline & & 10871 & & & \\
\hline WI38 ECM vs. HDF & 2000 & -18371 to & No & ns & 0.9933 \\
\hline & & & & & \\
\hline Row 4 & & & & & \\
\hline FN vs. IMR90 ECM & 160000 & $\begin{array}{l}139629 \text { to } \\
180371\end{array}$ & Yes & $* * * *$ & $<0.0001$ \\
\hline FN vs. WI38 ECM & 115000 & $\begin{array}{l}94629 \text { to } \\
135371\end{array}$ & Yes & $* * * *$ & $<0.0001$ \\
\hline FN vs. HDF & 120000 & $\begin{array}{l}99629 \text { to } \\
140371\end{array}$ & Yes & $* * * *$ & $<0.0001$ \\
\hline IMR90 ECM vs. WI38 ECM & -45000 & $\begin{array}{l}-65371 \text { to }- \\
24629\end{array}$ & Yes & $* * * *$ & $<0.0001$ \\
\hline IMR90 ECM vs. HDF & -40000 & $\begin{array}{l}-60371 \text { to }- \\
19629\end{array}$ & Yes & $* * * * *$ & $<0.0001$ \\
\hline WI38 ECM vs. HDF & 5000 & $\begin{array}{l}-15371 \text { to } \\
25371\end{array}$ & No & ns & 0.9094 \\
\hline
\end{tabular}

TABLE XIV

A549 ALAMAR BLUE STATISTICAL ANALYSIS

\begin{tabular}{|c|c|c|c|c|}
\hline A549 Alamar blue & & & & \\
\hline \multicolumn{5}{|c|}{ Within each row, compare columns (simple effects within rows) } \\
\hline & & & & \\
\hline Number of families & 4 & & & \\
\hline $\begin{array}{l}\text { Number of comparisons per } \\
\text { family }\end{array}$ & 6 & & & \\
\hline Alpha & 0.05 & & & \\
\hline $\begin{array}{l}\text { Tukey's multiple } \\
\text { comparisons test }\end{array}$ & $\begin{array}{l}\text { Mean } \\
\text { Diff. }\end{array}$ & $95 \%$ CI of diff. & Significant? & $\begin{array}{l}\text { Adjusted P } \\
\text { Value }\end{array}$ \\
\hline \multicolumn{5}{|l|}{ Row 1} \\
\hline FN vs. IMR90 ECM & $1.987 \mathrm{E}-08$ & $\begin{array}{l}-0.03641 \text { to } \\
0.03641\end{array}$ & No & $>0.9999$ \\
\hline FN vs. WI38 ECM & $\begin{array}{r}-1.987 \mathrm{E}- \\
08 \\
\end{array}$ & $\begin{array}{l}-0.03641 \text { to } \\
0.03641\end{array}$ & No & $>0.9999$ \\
\hline FN vs. HDF ECM & $1.987 \mathrm{E}-08$ & $\begin{array}{l}-0.03641 \text { to } \\
0.03641\end{array}$ & No & $>0.9999$ \\
\hline IMR90 ECM vs. WI38 ECM & $\begin{array}{r}-3.974 \mathrm{E}- \\
08 \\
\end{array}$ & $\begin{array}{l}-0.03641 \text { to } \\
0.03641\end{array}$ & No & $>0.9999$ \\
\hline IMR90 ECM vs. HDF ECM & 0 & -0.03641 to & No & $>0.9999$ \\
\hline
\end{tabular}




\begin{tabular}{|c|c|c|c|c|}
\hline & & 0.03641 & & \\
\hline WI38 ECM vs. HDF ECM & $3.974 \mathrm{E}-08$ & $\begin{array}{l}-0.03641 \text { to } \\
0.03641\end{array}$ & No & $>0.9999$ \\
\hline \multicolumn{5}{|l|}{ Row 2} \\
\hline FN vs. IMR90 ECM & 0.09386 & 0.05745 to 0.1303 & Yes & $<0.0001$ \\
\hline FN vs. WI38 ECM & 0.02694 & $\begin{array}{l}-0.009478 \text { to } \\
0.06335\end{array}$ & No & 0.2077 \\
\hline FN vs. HDF ECM & 0.06571 & 0.02929 to 0.1021 & Yes & 0.0002 \\
\hline IMR90 ECM vs. WI38 ECM & -0.06693 & $\begin{array}{l}-0.1033 \text { to }- \\
0.03051\end{array}$ & Yes & 0.0001 \\
\hline IMR90 ECM vs. HDF ECM & -0.02816 & $\begin{array}{l}-0.06457 \text { to } \\
0.008258\end{array}$ & No & 0.1765 \\
\hline WI38 ECM vs. HDF ECM & 0.03877 & $\begin{array}{l}0.002359 \text { to } \\
0.07519\end{array}$ & Yes & 0.0334 \\
\hline \multicolumn{5}{|l|}{ Row 3} \\
\hline FN vs. IMR90 ECM & 0.2109 & 0.1745 to 0.2474 & Yes & $<0.0001$ \\
\hline FN vs. WI38 ECM & 0.1547 & 0.1183 to 0.1911 & Yes & $<0.0001$ \\
\hline FN vs. HDF ECM & 0.2077 & 0.1713 to 0.2441 & Yes & $<0.0001$ \\
\hline IMR90 ECM vs. WI38 ECM & -0.05628 & $\begin{array}{l}-0.09270 \text { to }- \\
0.01987\end{array}$ & Yes & 0.0011 \\
\hline IMR90 ECM vs. HDF ECM & -0.003285 & $\begin{array}{l}-0.03970 \text { to } \\
0.03313\end{array}$ & No & 0.9948 \\
\hline WI38 ECM vs. HDF ECM & 0.053 & $\begin{array}{l}0.01659 \text { to } \\
0.08941\end{array}$ & Yes & 0.0022 \\
\hline \multicolumn{5}{|l|}{ Row 4} \\
\hline FN vs. IMR90 ECM & 0.2113 & 0.1749 to 0.2477 & Yes & $<0.0001$ \\
\hline FN vs. WI38 ECM & 0.1586 & 0.1222 to 0.1950 & Yes & $<0.0001$ \\
\hline FN vs. HDF ECM & 0.1954 & 0.1590 to 0.2318 & Yes & $<0.0001$ \\
\hline IMR90 ECM vs. WI38 ECM & -0.05269 & $\begin{array}{l}-0.08910 \text { to }- \\
0.01627\end{array}$ & Yes & 0.0024 \\
\hline IMR90 ECM vs. HDF ECM & -0.01586 & $\begin{array}{l}-0.05228 \text { to } \\
0.02055\end{array}$ & No & 0.6434 \\
\hline WI38 ECM vs. HDF ECM & 0.03682 & $\begin{array}{l}0.0004103 \text { to } \\
0.07324\end{array}$ & Yes & 0.0467 \\
\hline
\end{tabular}

TABLE XV 


\section{H358 ALAMAR BLUE STATISTICAL ANALYSIS}

\begin{tabular}{|c|c|c|c|c|}
\hline \multirow{2}{*}{\multicolumn{5}{|c|}{\begin{tabular}{l|l|l|} 
H358 Alamar Blue & & \\
Within each row, compare columns (simple effects within rows)
\end{tabular}}} \\
\hline & & & & \\
\hline Number of families & 4 & & & \\
\hline $\begin{array}{l}\text { Number of comparisons per } \\
\text { family }\end{array}$ & 6 & & & \\
\hline Alpha & 0.05 & & & \\
\hline $\begin{array}{l}\text { Tukey's multiple } \\
\text { comparisons test }\end{array}$ & $\begin{array}{l}\text { Mean } \\
\text { Diff. }\end{array}$ & $95 \%$ CI of diff. & Significant? & $\begin{array}{l}\text { Adjusted P } \\
\text { Value }\end{array}$ \\
\hline \multicolumn{5}{|l|}{ Row 1} \\
\hline FN vs. IMR90 ECM & $\begin{array}{r}-1.987 \mathrm{E}- \\
08\end{array}$ & $\begin{array}{l}-0.06557 \text { to } \\
0.06557\end{array}$ & No & $>0.9999$ \\
\hline FN vs. WI38 ECM & $\begin{array}{r}-1.987 \mathrm{E}- \\
08\end{array}$ & $\begin{array}{l}-0.06557 \text { to } \\
0.06557\end{array}$ & No & $>0.9999$ \\
\hline FN vs. HDF ECM & $\begin{array}{r}-1.987 \mathrm{E}- \\
08\end{array}$ & $\begin{array}{l}-0.06557 \text { to } \\
0.06557\end{array}$ & No & $>0.9999$ \\
\hline IMR90 ECM vs. WI38 ECM & 0 & $\begin{array}{l}-0.06557 \text { to } \\
0.06557\end{array}$ & No & $>0.9999$ \\
\hline IMR90 ECM vs. HDF ECM & 0 & $\begin{array}{l}-0.06557 \text { to } \\
0.06557\end{array}$ & No & $>0.9999$ \\
\hline WI38 ECM vs. HDF ECM & 0 & $\begin{array}{l}-0.06557 \text { to } \\
0.06557\end{array}$ & No & $>0.9999$ \\
\hline \multicolumn{5}{|l|}{ Row 2} \\
\hline FN vs. IMR90 ECM & 0.08628 & $\begin{array}{l}0.02071 \text { to } \\
0.1518\end{array}$ & Yes & 0.0061 \\
\hline FN vs. WI38 ECM & 0.1088 & $\begin{array}{l}0.04320 \text { to } \\
0.1743\end{array}$ & Yes & 0.0005 \\
\hline FN vs. HDF ECM & 0.1004 & $\begin{array}{l}0.03486 \text { to } \\
0.1660\end{array}$ & Yes & 0.0013 \\
\hline IMR90 ECM vs. WI38 ECM & 0.0225 & $\begin{array}{l}-0.04307 \text { to } \\
0.08807\end{array}$ & No & 0.7893 \\
\hline IMR90 ECM vs. HDF ECM & 0.01415 & $\begin{array}{l}-0.05142 \text { to } \\
0.07972\end{array}$ & No & 0.9359 \\
\hline WI38 ECM vs. HDF ECM & -0.008342 & $\begin{array}{l}-0.07391 \text { to } \\
0.05723\end{array}$ & No & 0.9857 \\
\hline \multicolumn{5}{|l|}{ Row 3} \\
\hline FN vs. IMR90 ECM & 0.2414 & 0.1759 to & Yes & $<0.0001$ \\
\hline
\end{tabular}




\begin{tabular}{|c|c|c|c|c|}
\hline & & 0.3070 & & \\
\hline FN vs. WI38 ECM & 0.2667 & $\begin{array}{l}0.2011 \text { to } \\
0.3322\end{array}$ & Yes & $<0.0001$ \\
\hline FN vs. HDF ECM & 0.2455 & $\begin{array}{l}0.1800 \text { to } \\
0.3111\end{array}$ & Yes & $<0.0001$ \\
\hline IMR90 ECM vs. WI38 ECM & 0.02523 & $\begin{array}{l}-0.04034 \text { to } \\
0.09080\end{array}$ & No & 0.726 \\
\hline IMR90 ECM vs. HDF ECM & 0.004093 & $\begin{array}{l}-0.06148 \text { to } \\
0.06966\end{array}$ & No & 0.9982 \\
\hline WI38 ECM vs. HDF ECM & -0.02114 & $\begin{array}{l}-0.08671 \text { to } \\
0.04443\end{array}$ & No & 0.8185 \\
\hline \multicolumn{5}{|l|}{ Row 4} \\
\hline FN vs. IMR90 ECM & 0.294 & $\begin{array}{l}0.2284 \text { to } \\
0.3596\end{array}$ & Yes & $<0.0001$ \\
\hline FN vs. WI38 ECM & 0.3383 & $\begin{array}{l}0.2727 \text { to } \\
0.4038\end{array}$ & Yes & $<0.0001$ \\
\hline FN vs. HDF ECM & 0.3398 & $\begin{array}{l}0.2742 \text { to } \\
0.4054\end{array}$ & Yes & $<0.0001$ \\
\hline IMR90 ECM vs. WI38 ECM & 0.04428 & $\begin{array}{l}-0.02129 \text { to } \\
0.1098\end{array}$ & No & 0.2785 \\
\hline IMR90 ECM vs. HDF ECM & 0.0458 & $\begin{array}{l}-0.01977 \text { to } \\
0.1114\end{array}$ & No & 0.2514 \\
\hline WI38 ECM vs. HDF ECM & 0.001515 & $\begin{array}{l}-0.06405 \text { to } \\
0.06708\end{array}$ & No & $>0.9999$ \\
\hline
\end{tabular}

TABLE XVI

HPL1D ALAMAR BLUE STATISTICAL ANALYSIS

\begin{tabular}{|l|r|l|l|l|}
\hline HPL1D Alamar Blue & & & \\
\hline Within each row, compare columns (simple effects within rows) & & \\
\hline & & & & \\
\hline Number of families & 4 & & & \\
\hline $\begin{array}{l}\text { Number of comparisons per } \\
\text { family }\end{array}$ & 6 & & & \\
\hline Alpha & 0.05 & & & \\
\hline & & & & \\
\hline Tukey's multiple & Mean & 95\% CI of diff. & Significant? & Adjusted P \\
\hline
\end{tabular}




\begin{tabular}{|c|c|c|c|c|}
\hline comparisons test & Diff. & & & Value \\
\hline \multicolumn{5}{|l|}{ Row 1} \\
\hline FN vs. IMR90 ECM & $\begin{array}{r}-1.987 \mathrm{E}- \\
08 \\
\end{array}$ & $\begin{array}{l}-0.05237 \text { to } \\
0.05237\end{array}$ & No & $>0.9999$ \\
\hline FN vs. WI38 ECM & 0 & $\begin{array}{l}-0.05237 \text { to } \\
0.05237\end{array}$ & No & $>0.9999$ \\
\hline FN vs. HDF ECM & $2.782 \mathrm{E}-07$ & $\begin{array}{l}-0.05237 \text { to } \\
0.05237\end{array}$ & No & $>0.9999$ \\
\hline IMR90 ECM vs. WI38 ECM & $1.987 \mathrm{E}-08$ & $\begin{array}{l}-0.05237 \text { to } \\
0.05237\end{array}$ & No & $>0.9999$ \\
\hline IMR90 ECM vs. HDF ECM & $2.98 \mathrm{E}-07$ & $\begin{array}{l}-0.05237 \text { to } \\
0.05237\end{array}$ & No & $>0.9999$ \\
\hline WI38 ECM vs. HDF ECM & $2.782 \mathrm{E}-07$ & $\begin{array}{l}-0.05237 \text { to } \\
0.05237\end{array}$ & No & $>0.9999$ \\
\hline \multicolumn{5}{|l|}{ Row 2} \\
\hline FN vs. IMR90 ECM & 0.08531 & 0.03293 to 0.1377 & Yes & 0.0006 \\
\hline FN vs. WI38 ECM & 0.1229 & 0.07049 to 0.1752 & Yes & $<0.0001$ \\
\hline FN vs. HDF ECM & 0.0195 & $\begin{array}{l}-0.03287 \text { to } \\
0.07187\end{array}$ & No & 0.7455 \\
\hline IMR90 ECM vs. WI38 ECM & 0.03755 & $\begin{array}{l}-0.01482 \text { to } \\
0.08993\end{array}$ & No & 0.231 \\
\hline IMR90 ECM vs. HDF ECM & -0.06581 & $\begin{array}{l}-0.1182 \text { to }- \\
0.01343\end{array}$ & Yes & 0.0093 \\
\hline WI38 ECM vs. HDF ECM & -0.1034 & $\begin{array}{l}-0.1557 \text { to }- \\
0.05099\end{array}$ & Yes & $<0.0001$ \\
\hline \multicolumn{5}{|l|}{ Row 3} \\
\hline FN vs. IMR90 ECM & 0.3145 & 0.2621 to 0.3669 & Yes & $<0.0001$ \\
\hline FN vs. WI38 ECM & 0.2348 & 0.1824 to 0.2872 & Yes & $<0.0001$ \\
\hline FN vs. HDF ECM & 0.1816 & 0.1292 to 0.2340 & Yes & $<0.0001$ \\
\hline IMR90 ECM vs. WI38 ECM & -0.07967 & $\begin{array}{l}-0.1320 \text { to }- \\
0.02730\end{array}$ & Yes & 0.0014 \\
\hline IMR90 ECM vs. HDF ECM & -0.1329 & $\begin{array}{l}-0.1853 \text { to }- \\
0.08051\end{array}$ & Yes & $<0.0001$ \\
\hline WI38 ECM vs. HDF ECM & -0.05321 & $\begin{array}{l}-0.1056 \text { to }- \\
0.0008385\end{array}$ & Yes & 0.0453 \\
\hline \multicolumn{5}{|l|}{ Row 4} \\
\hline FN vs. IMR90 ECM & 0.3231 & 0.2708 to 0.3755 & Yes & $<0.0001$ \\
\hline FN vs. WI38 ECM & 0.2765 & 0.2242 to 0.3289 & Yes & $<0.0001$ \\
\hline
\end{tabular}




\begin{tabular}{|l|r|l|l|c|}
\hline FN vs. HDF ECM & 0.2025 & 0.1501 to 0.2549 & Yes & $<0.0001$ \\
\hline IMR90 ECM vs. WI38 ECM & -0.04661 & -0.09898 to & No & 0.0952 \\
& & 0.005764 & & \\
\hline IMR90 ECM vs. HDF ECM & -0.1206 & -0.1730 to - & Yes & $<0.0001$ \\
& & 0.06827 & & 0.003 \\
\hline WI38 ECM vs. HDF ECM & -0.07403 & -0.1264 to - & Yes & \\
& & 0.02166 & & \\
\hline
\end{tabular}

TABLE XVII

XENOGRAFT VOLUME STATISTICAL ANALYSIS

\begin{tabular}{|l|l|}
\hline Xenograft Tumor Volume & Data 1 \\
\hline Column B & A549 +PBS \\
\hline vs. & vs. \\
\hline Column A & A549+ECM \\
\hline & \\
\hline Unpaired t test & \\
\hline P value & 0.0718 \\
\hline P value summary & ns \\
\hline Significantly different? $(\mathrm{P}<0.05)$ & No \\
\hline One- or two-tailed P value? & Two-tailed \\
\hline t, df & $\mathrm{t}=1.884 \mathrm{df}=24$ \\
\hline & \\
\hline How big is the difference? & \\
\hline Mean \pm SEM of column A & $334.3 \pm 48.20, \mathrm{n}=13$ \\
\hline Mean \pm SEM of column B & $223.3 \pm 33.88, \mathrm{n}=13$ \\
\hline Difference between means & $-111.0 \pm 58.92$ \\
\hline 95\% confidence interval & -232.6 to 10.62 \\
\hline R squared & 0.1288 \\
\hline & \\
\hline F test to compare variances & \\
\hline F,DFn, Dfd & $2.024,12,12$ \\
\hline P value & 0.2364 \\
\hline P value summary & ns \\
\hline Significantly different? (P $<0.05)$ & No \\
\hline
\end{tabular}

TABLE XVIII

XENOGRAFT WEIGHT STATISTICAL ANALYSIS

\begin{tabular}{|l|l|}
\hline Xenograft Weights & Data 1 \\
\hline & \\
\hline
\end{tabular}




\begin{tabular}{|l|l|}
\hline Column B & A549+PBS \\
\hline vs. & vs. \\
\hline Column A & A549+ECM \\
\hline & \\
\hline Unpaired t test & 0.0261 \\
\hline P value & $*$ \\
\hline P value summary & Yes \\
\hline $\begin{array}{l}\text { Significantly different? }(\mathrm{P}< \\
0.05)\end{array}$ & \\
\hline One- or two-tailed P value? & Two-tailed \\
\hline t, df & $\mathrm{t}=2.372 \mathrm{df}=24$ \\
\hline & \\
\hline How big is the difference? & \\
\hline Mean \pm SEM of column A & $0.2346 \pm 0.03717, \mathrm{n}=13$ \\
\hline Mean \pm SEM of column B & $0.1362 \pm 0.01849, \mathrm{n}=13$ \\
\hline Difference between means & $-0.09846 \pm 0.04151$ \\
\hline 95\% confidence interval & -0.1841 to -0.01278 \\
\hline R squared & 0.1899 \\
\hline & \\
\hline F test to compare variances & \\
\hline F,DFn, Dfd & $4.043,12,12$ \\
\hline P value & 0.0223 \\
\hline P value summary & $*$ \\
\hline $\begin{array}{l}\text { Significantly different? }(\mathrm{P}< \\
0.05)\end{array}$ & Yes \\
\hline
\end{tabular}

TABLE XIX

XENOGRAFT WEIGHT STATISTICAL ANALYSIS

\begin{tabular}{|l|r|l|l|l|r|}
\hline Trans-well Migration & & & & & \\
\hline Number of families & 1 & & & & \\
\hline $\begin{array}{l}\text { Number of comparisons per } \\
\text { family }\end{array}$ & 6 & & & & \\
\hline Alpha & 0.05 & & & & \\
\hline & & $\begin{array}{l}\text { 95\% CI of } \\
\text { diff. }\end{array}$ & Significant & Summary & $\begin{array}{l}\text { Adjusted P } \\
\text { Value }\end{array}$ \\
\hline $\begin{array}{l}\text { Tukey's multiple } \\
\text { comparisons test }\end{array}$ & Mean Diff. & & & \\
\hline A549 FN vs. A549 IMR90 & & $\begin{array}{l}-173.8 \text { to - } \\
88.15\end{array}$ & Yes & $* *$ & 0.0021 \\
\hline A549 FN vs. A549 WI38 & -131 & -222.1 to - & Yes & $* *$ & 0.0081 \\
\hline
\end{tabular}




\begin{tabular}{|l|l|l|l|l|l|}
\hline & & 69.90 & & \\
\hline A549 FN vs. A549 HDF & -146 & $\begin{array}{l}-162.9 \text { to }- \\
101.6\end{array}$ & Yes & $* * *$ & 0.0008 \\
\hline & & & & & \\
\hline & & & & & \\
\hline & & & & & \\
\hline
\end{tabular}




\section{REFERENCES}

American Cancer Society. "Non-small cell lung cancer survival rates by stage". March 2015. www.Cancer.org

Bao, L., et al. (1994). "Effects of inoculation site and Matrigel on growth and metastasis of human breast cancer cells." Br J Cancer 70(2): 228-232.

Benham-Pyle, B. W., et al. (2015). "Cell adhesion. Mechanical strain induces E-cadherindependent Yap1 and beta-catenin activation to drive cell cycle entry." Science 348(6238): 10241027.

Benton, G., et al. (2011). "Multiple uses of basement membrane-like matrix (BME/Matrigel) in vitro and in vivo with cancer cells." Int J Cancer 128(8): 1751-1757.

Blaauboer, M. E., et al. (2014). "Extracellular matrix proteins: a positive feedback loop in lung fibrosis?" Matrix Biol 34: 170-178.

Braun, F., et al. (2011). "Serum-nutrient starvation induces cell death mediated by Bax and Puma that is counteracted by $\mathrm{p} 21$ and unmasked by Bcl-x(L) inhibition." PLoS One 6(8): e23577.

Butcher, D. T., et al. (2009). "A tense situation: forcing tumour progression." Nat Rev Cancer 9(2): 108-122.

Buttery, R., et al. (2004). "Galectin-3: differential expression between small-cell and non-smallcell lung cancer." Histopathology 44(4): 339-344.

Caccavari, F., Valdembri, D., Sandri, C., Bussolino, F., \& Serini, G. (2010). Integrin signaling and lung cancer. Cell Adhesion \& Migration, 4(1), 124-129

Cirri, P. and P. Chiarugi (2011). "Cancer associated fibroblasts: the dark side of the coin." Am J Cancer Res 1(4): 482-497

Copland, I. B. and M. Post (2007). "Stretch-activated signaling pathways responsible for early response gene expression in fetal lung epithelial cells." J Cell Physiol 210(1): 133-143.

Cox, T. R. and J. T. Erler (2011). "Remodeling and homeostasis of the extracellular matrix: implications for fibrotic diseases and cancer." Dis Model Mech 4(2): 165-178

Das, M. and H. Wakelee (2012). "Targeting VEGF in lung cancer." Expert Opin Ther Targets 16(4): 395-406

Gao, Y., et al. (2010). "LKB1 inhibits lung cancer progression through lysyl oxidase and extracellular matrix remodeling." Proc Natl Acad Sci U S A 107(44): 18892-18897. 
Hadler-Olsen, E., et al. (2013). "Matrix metalloproteinases in cancer: their value as diagnostic and prognostic markers and therapeutic targets." Tumour Biol 34(4): 2041-2051.

Hoelder, S., et al. (2012). "Discovery of small molecule cancer drugs: successes, challenges and opportunities." Mol Oncol 6(2): 155-176.

Huijbers, I. J., et al. (2010). "A role for fibrillar collagen deposition and the collagen internalization receptor endo180 in glioma invasion." PLoS One 5(3): e9808.

Ihde, D. C. (1992). "Chemotherapy of lung cancer." N Engl J Med 327(20): 1434-1441.

Jensen, M. M., et al. (2008). "Tumor volume in subcutaneous mouse xenografts measured by microCT is more accurate and reproducible than determined by $18 \mathrm{~F}-\mathrm{FDG}$-microPET or external caliper." BMC Med Imaging 8: 16.

Jin, D., et al. (2010). "CD73 on tumor cells impairs antitumor T-cell responses: a novel mechanism of tumor-induced immune suppression." Cancer Res 70(6): 2245-2255.

Khaitan, D., et al. (2009). "Role of KCNMA1 gene in breast cancer invasion and metastasis to brain." BMC Cancer 9: 258.

Lee, H. O., et al. (2011). "FAP-overexpressing fibroblasts produce an extracellular matrix that enhances invasive velocity and directionality of pancreatic cancer cells." BMC Cancer 11: 245. Liu, F. T. and G. A. Rabinovich (2005). "Galectins as modulators of tumour progression." Nat Rev Cancer 5(1): 29-41.

Lu, P., et al. (2012). "The extracellular matrix: a dynamic niche in cancer progression." J Cell Biol 196(4): 395-406.

Luppi, F., et al. (2007). "Interleukin-8 stimulates cell proliferation in non-small cell lung cancer through epidermal growth factor receptor transactivation." Lung Cancer 56(1): 25-33.

Meijering, E., et al. (2012). "Methods for cell and particle tracking." Methods Enzymol 504: 183-200.

Na, S. S., et al. (2015). "Stanniocalcin-2 (STC2): A potential lung cancer biomarker promotes lung cancer metastasis and progression." Biochim Biophys Acta 1854(6): 668-676.

Oskarsson, T. (2013). "Extracellular matrix components in breast cancer progression and metastasis." Breast 22 Suppl 2: S66-72.

Pasqualato, A., et al. (2013). "Shape in migration: Quantitative image analysis of migrating chemoresistant HCT-8 colon cancer cells." Cell Adh Migr 7(5): 450-459. 
Pio, R., et al. (2013). "Complement inhibition: a promising concept for cancer treatment." Semin Immunol 25(1): 54-64.

Pio, R., et al. (2014). "The Role of Complement in Tumor Growth." Adv Exp Med Biol 772: 229-262.

Schwendener RA., et al. (2014). "The Tumor Microenvironment as Target for New Cancer Therapies" Frontiers in Clinical Drug Research Vol 1: 3-68

Seger, R. and E. G. Krebs (1995). "The MAPK signaling cascade." Faseb j 9(9): 726-735.

Serebriiskii, I., et al. (2008). "Fibroblast-derived 3D matrix differentially regulates the growth and drug-responsiveness of human cancer cells." Matrix Biol 27(6): 573-585.

Soucy, P. A. and L. H. Romer (2009). "Endothelial cell adhesion, signaling, and morphogenesis in fibroblast-derived matrix." Matrix Biol 28(5): 273-283.

Soucy, P. A., et al. (2015). "Oriented matrix promotes directional tubulogenesis." Acta Biomater 11: $264-273$.

Wood, S. L., et al. (2014). "The role of the tumor-microenvironment in lung cancer-metastasis and its relationship to potential therapeutic targets." Cancer Treat Rev 40(4): 558-566.

Xiao, D. and J. He (2010). "Epithelial mesenchymal transition and lung cancer." J Thorac Dis 2(3): 154-159.

Yang, N., et al. (2011). "Syndecan-1 in breast cancer stroma fibroblasts regulates extracellular matrix fiber organization and carcinoma cell motility." Am J Pathol 178(1): 325-335

Yin, Z., et al. (2013). "A screen for morphological complexity identifies regulators of switch-like transitions between discrete cell shapes." Nat Cell Biol 15(7): 860-871.

Zhang, B. (2010). "CD73: A novel target for cancer immunotherapy." Cancer Res 70(16): 64076411. 
MICHAEL T. SCHERZER

\section{Education}

University of Louisville

M.Eng. Department of Bioengineering

B.S. Department of Bioengineering (BE)
Louisville, KY

Summer 2015

Fall 2009-Summer 2013

GPA 3.2/4.0

\section{Experience}

Parallel Products, Inc.

Quality Control/Chemical Analyst

James Graham Brown Cancer Center
Louisville, KY

May 2012-December 2012

Louisville, KY 


\section{Publications}

Saurabh, K.*, Scherzer, M.*, Shah, P, Mims, A., Lockwood, W., Kraft, A., \& Beverly, L. (2014). The PIM family of oncoproteins: small kinases with huge implications in myeloid leukemogenesis and as therapeutic targets. Oncotarget, 5(18), 8503-8514

Saurabh K*, Scherzer M*, Song A, Yip KW, Reed JC, et al. Dissecting the In Vivo Leukemogenic Potency of Bclxl. J Leuk 3: 158

*Contributed equally to the work

\section{Poster Abstracts and Presentations}

Michael Scherzer, Morgan Stathem, Patrick Roddy, Leah Siskind, Levi Beverly. An Unbiased Approach to Assess the Role of Sphingolipid Metabolism in Cancer Biology. $7^{\text {th }}$ Symposium: Mechanisms and Models of Cancer, 2013. La Jolla, CA.

Morgan Stathem, Lavonna Casson, Michael Scherzer, Levi Beverly, Leah Siskind. Tumor Cell Glycosphingolipid Metabolism as a Target for the Treatment of Cancers. $7^{\text {th }}$ Symposium: Mechanisms and Models of Cancer, 2013. La Jolla, CA.

Michael Scherzer, Morgan Stathem, Leah Siskind, Levi Beverly. The Role of Sphingosine Kinase 2 in Leukemogensis. University of Louisville E-Expo, 2014. Louisville, KY.

Kumar Saurabh, Michael Scherzer, Parag Shah, Alice Mims, Andrew Kraft, Levi Beverly. PIM Kinases: a Small Family with a Big Role in Myeloid Leukemia. Tenth International Workshop on Molecular Aspects of Myeloid Stem Cell Development and Leukemia, 2014. Cincinnati, OH.

Michael Scherzer, Patricia Soucy, Levi Beverly. Using Fibroblast-derived 3D matrices to dissect Micro Environmental Cues Critical for Lung Cancer Progression and Metastasis. Research! Louisville, 2014. Louisville, KY.

\section{Teaching Experience}

\section{Artificial Organs (BE 683)}

A lecture on hearing physiology and pathology and biomedical devices for therapy

\section{Micro-Electrical-Mechanical-Systems (BE 680)}

A lecture on Controlling the Cellular Micronenviroment, A topic covered from chapters of George Eng and Milicia Radisic

Biomaterials (BE 650)

A lecture on tissue engineering approaches that enhance wound healing 
Honors

2012-2013. Speed School of Engineering Dean's List 